\title{
BAJYA IBN PAKUDA
}

\section{(1040 - ca. 1110 e.c.)}

Bajya ibn Pakuda y su obra Doctrina de los deberes de los corazones es el tema de este capítulo.

El acercamiento al tema consistirá, en primer lugar, en la presentación de los aspectos biográficos del autor, asi como de los rasgos fundamentales de su obra.

A continuación, presentamos un resumen del contenido de Jovot Halvavot (hbr. Deberes de los corazones), cuyo objetivo es poner en conocimiento del lector los contenidos de la obra, como también contextualizar la presentación ofrecida.

Por otro lado, solo fue posible hallar un ejemplar de la obra. Por lo tanto, no es erróneo suponer que ella no será de fácil acceso para quien desee acercarse a ella.

El estudio que se ofrece de esta obra consiste en la presentación de sus vertientes más sobresalientes. Esto significa que, por un lado, realizamos un acercamiento que la acota en su sentido de literatura midráśica y como tal la articula dentro de una milenaria tradición de productos culturales que responden a planes y objetivos que, presentes también en Jovot Halvavot, hacen de ella una clara expresión de continuidad tradicional. Por otro lado, se plantea el estudio de la obra en tanto discurso retórico que entronca con la tradición gentil y cuanto atañe al uso del lenguaje como medio de persuasión.

En el segundo enfoque se ponen de relieve aquellos aspectos de la tradición retórica que el autor despliega con más evidencia y que constituyen un rasgo relevante dentro del plan y sentido general de la obra.

Para concluir este acercamiento, se presenta un corpus de parábolas que constituye el lugar de encuentro de las dos vertientes realizadas en la obra. Las parábolas son como una muestra de la construcción de pruebas técnicas, desde un punto de vista retórico y de lo que es el método de enseñanza de la literatura midrášica.

\section{EL AUTOR Y SU OBRA}

Bajya ben Yosefibn Pakuda fue un poeta y un filósofo que nació en España en el año 1040 y murió aproximadamente en el 1110 e.c.

De su vida han llegado hasta nuestros días muy pocos antecedentes como para permitir establecer una biografia más completa que la que aquí detallamos: 
Se le conoció con el apodo de dayán (juez), apodo que hace referencia a su actuación como magistrado de un tribunal rabínico en Zaragoza ${ }^{2 !}$.

Podemos decir con certeza que se benefició del ambiente cultural que a la fecha existía en la corte de Zaragoza. Ibn Pakuda vivió en la generación siguiente a la de ibn Gabiroly, como en éste y en la mayor parte de los autores hispano-hebreos del período, predominaba también en ibn Pakuda una marcada tendencia moral-religiosa, traducida en la creación de una teología moral que provocó gran aceptación en las masas. Prueba de ello es que su obra más importante, la Doctrina de los deberes de los corazones, fue muy leída entre la gente de su época, pese a que no ejerció notable influencia en el nivel de las autoridades judías o de la doctrina oficial.

Doctrina de los deberes de los corazones (Jovot halvavot) es una obra de carácter filosófico-religioso, de la que no puede disociarse su concepción estética y su valor poético.

El principio fundamental de su doctrina es la superioridad de la comunión con Dios respecto de la observancia de las leyes y de la conducta moral, concepto que revela el fondo místico de la filosofía de ibn Pakuda, filosofia fuertemente influida por el kalam árabe ${ }^{22}$, por el neoplatonismo y por la literatura ascética y sufi $^{23}$.

El tema central de Jovot halvavot es que lo principal en la vida debe ser el sentimiento religioso y que las ciencias, incluso la ciencia de la Tora ${ }^{24}$ y la misma Ley, a lo menos en lo que tiene de prescripciones rituales, está muy por debajo de los deberes de la conciencia, traducidos en una vida santa, llena de temor de Dios.

Bajya ibn Pakuda produjo también poesía, toda ella de índole religiosa, pero los textos de su obra poética no se encuentran a nuestra disposición.

Sin duda, la Doctrina de los deberes de los corazones es su obra más importante, tanto en su época como para quienes vinieron después. Su importancia aparece en lo que David Gonzalo Maeso nos dice:

21 Tribunal rabinico:(...) la historia del sistema judicial se remonta al periodo de la formación nacional y deriva, según la tradición, de Moisés. En Exodo cap. 18 se cuenta que el gran legislador nombró jueces cuando los israelitas se encontraban aún en el exilio. La ley biblica exige que se nombren jueces en todas las ciudades del pais (Deut. 16:18), y al rey Jeosafat se le atribuyó la creación de un sistema judicial basado en una red de tribunales en Eretz Israel (1 Crónicas 19:5-7).

(...) En la organización judicial de la antigua Palestina encontramos tres clases de tribunales: el primero y más sencillo, el tribunal ordinario, era exclusivamente judicial; los otros dos, el pequeno consejo de los ancianos de la ciudad y el gran consejo de la nación tenían funciones legislativas y judiciales al mismo tiempo (...). Sin embargo, los tribunales judios no tenian facultad para imponer la pena de muerte salvo en casos excepcionales. Parece ser que los tribunales palestinos bajo la dominación romana perdieron ese derecho en el año 30 de la era comủn. En España se dictaron, aunque en muy raras ocasiones, sentencias de muerte por tribunales judios hasta 1380 . La ejecución de la sentencia incumbia a las autoridades cristianas (cfr. E.J.C., vol.10, pp. 301-302).

22 El kaiam árabe es la doctrina teológica musulmana que subrayaba el libre albedrio, y hacia de Dios el origen de todos los actos y acontecimientos.

23 Literatura suff = literatura mistica árabe. 
Es muy posible que esta obra influyera en los escolástícos, y algunas palmarias coincidencias dan pie para afirmar que Santo Tomás pudo tener en cuenta las pruebas de la existencia de Dios expuestas por Bajya ibn Pakuda en su Jovot halvavot ${ }^{25}$.

El propósito que guía la actividad de este autor es perfeccionar la vida religiosa y moral de su pueblo a través del estudio de un asunto que se encontraba olvidado por los tratados. La mayor preocupación de ibn Pakuda es que las formas religiosas amenazan vaciarse de contenidos. Los motivos que lo guian en su tarea son principalmente dos:

a) La ausencia de una obra que tratara explícitamente sobre los deberes de los corazones, y

b) la necesidad de ella: ibn Pakuda siente temor, al igual que sus antepasados, de la vaciedad de las prácticas religiosas.

Al respecto señala:

Quien quiera que se consagre solamente al estudio de la Torá, es semejante al ateo, como está dicho: 'Durante largo tiempo Israel no tuvo ya Dios verdadero, sacerdotes que fuesen maestros y ni aún la Torá'. Es necesario consagrarse a la Torá y a la caridad (Crónicas 15:3) ${ }^{26}$.

El primer paso estructurante de Jovot halvavot es la certeza del autor de que está cumpliendo con la palabra sagrada y con la tradición al ocuparse de una obra como ésta:

Dios da la sabiduria: el conocimiento y la inteligencia salen de su boca ${ }^{27}$ (Proverbios 51:6).

Los vértices sobre los que se apoya corresponden sin duda a la Torá y la tradición. La importancia de este hecho es que ibn Pakuda se plantea como un continuador y un perfeccionador de la vida moral y religiosa de su pueblo.

Debemos notar esto y destacarlo en toda su importancia, pues reviste un carácter definitorio y estructurante de una particular forma y visión de mundo. De ella podemos inferir los supuestos que guían el quehacer de nuestro autor. A nosotros nos corresponde actualizar y poner en circuito comunicativo su obra.

Dentro de este marco podemos entender el procedimiento de Pakuda cuando dice que el conocimiento se divide en tres partes o en tres ciencias:

Bajya ibn Pakuda señala en la Introducción a Doctrina de los deberes de los corazones que el conocimiento se divide en tres partes, tres ciencias, de las cuales la teologia es la superior. 
La ciencia superior es la Teología; ella permite el acercamiento a Dios y la comprensión de la Torá. Asimismo, otorga su justo lugar a cada una de las otras dos: a la ciencia de las cosas creadas, llamada en árabe $A$ l ilm al tibi, y a las matemáticas, llamada en árabe $A l$ ilm al-ilahi y que comprende la aritmética, la geometría, la astronomía y la música.

La ciencia de la Torá a su vez, se divide en dos partes: en deberes interiores y exteriores. Los deberes interiores son los del corazón. Esta es la razón por la cual ibn Pakuda dice que se debe estudiar por amor: "Estudiad por amor, toda gloria vendrá por añadidura" (Deuteronomio 30:22) , $^{28}$.

Al estudiar la tradición, ibn Pakuda comprobó que los deberes interiores estaban abandonados en los escritos y concluye que los tratados se limitaban a tres propósitos:

1) La exégesis y la aclaración del lenguaje y la gramática;

2) presentar en forma sumaria los preceptos, $y$

3) implantar la Torá por medio de demostraciones y de refutaciones a los incrédulos.

La conclusión a la que llega es la siguiente:

He investigado estos escritos, pero no encontré entre ellos ningún libro consagrado especialmente a los deberes interiores. He comprobado que la ciencia de los deberes del corazón estaba completamente abandonada: Nadie se ha ocupado de manera sistemática de sus principios y sus distintos aspectos ${ }^{29}$.

El resultado de este proceso introspectivo en la conciencia del autor y su puesta en práctica da como resultado la obra que a continuación presentamos. 


\section{DOCTRINA DE LOS DEBERES DE LOS CORAZONES}

\section{PRIMER PÓRTICO}

\section{LA UNIDAD DE DIOS}

Este primer pórtico se divide en diez capítulos. En cada uno de ellos se analiza el concepto que $i b n$ Pakuda quiere establecer y fundar como principio.

"La unidad de Dios" es el título del pórtico inicial y una marca ineludible sobre la que hay que acusar recibo, porque Shema Israel, Adonay elohenu, Adonai ejad (= "Oye Israel, el Señor nuestro Dios, el Señor es Uno") es el mandato y la profesión de fe original del pueblo judío y es también la proclama inicial del tema que trata este primer pórtico.

El autor señala que la confesión perfecta de la unidad de Dios depende de la capacidad de cada hombre, del desarrollo de su intelecto, pues no todos los hombres están igualmente capacitados o dotados. Así, entonces, aduce que debemos distinguir cuatro niveles:

1) quienes repiten sin comprender: éstos son los más simples;

2) quienes siguen la tradición;

3) quienes comprenden la unidad y la proclaman, pero la confunden con la unidad metafórica, $y$

4) quienes comprenden y proclaman la unidad de Dios y no la confunden con la unidad metafórica. Son los menos, pues siempre es reducido el número de los mejores.

El último nivel es el más alto y en donde el corazón, es decir, el sentimiento religioso se une en intensidad a la capacidad del intelecto. Cuando ambos se unen, entonces es posible la confesión perfecta de la unidad de Dios.

Pero como este es un grado difícil de alcanzar, es necesario analizar las dificultades y comprender, tanto por la razón como por la tradición, la necesidad de profesar la unidad perfecta de Dios.

Vemos pues, que las diferentes maneras de confesar la unidad de Dios dependen de la capacidad de cada hombre y que la ignorancia puede hacer errar al hombre, es decir, profesar en vez de la unidad real, la unidad metafórica (ver más adelante).

El hombre debe aspirar a comprender la unidad real, a lo que se accede con gran esfuerzo. Se hace necesario estudiar la Torá y las demás ciencias. El estudio debe realizarse por medios especulativos, mediante deducciones racionales, para así alcanzar el grado máximo de comprensión. 
Has conocido hoy y meditado en tu corazón

que el Señor es tu Dios ${ }^{30}$

(Deuteronomio 4:39).

La aplicación real de esta máxima permite que existan hombres mejor dispuestos y mejor dotados. Ellos son el filósofo y el profeta. Así lo explica ibn Pakuda:

Solamente pueden adorar la causa suprema y el principio primero, el profeta, por un ejercicio natural y el filósofo, por la ciencia adquirida. Todos los demás adoran otra cosa que no es la causa suprema, pues sólo conciben al ser compuesto ${ }^{3 !}$.

No obstante lo anterior, la obligación ineludible para todo hombre es el examen lógico de la realidad de Dios. Todo hombre debe, en la medida de sus fuerzas y capacidades, analizar por medio de su intelecto, la realidad de Dios. Esta obligación emana tanto de la razón como de la tradición, ya que este deber aparece dicho numerosas veces en las Escrituras:

La guardarás y la cumplirás, pues ella (la Torá) es vuestra sabiduría y vuestra inteligencia a ojos de los pueblos ${ }^{32}$

(Deuteronomio 4:6).

¿Cómo hacerlo? Existe un método de investigación de la realidad de Dios y conocimientos preliminares necesarios. Los pasos a seguir son: establecer su existencia, luego su unidad y, finalmente, si se trata de lo uno real o de lo uno metafórico. Solo de este modo el hombre puede proclamar, en forma perfecta, la unidad de Dios.

Los principios de demostración de la existencia de Dios son tres:

1) Nada se crea por sí mismo;

2) las causas antecedentes son limitadas en número, $y$,

3) todo ser compuesto es necesariamente creado.

Estos principios de demostración quedan probados a luz de la observación del mundo.

Todo lo que existe, necesariamente ha sido creado por alguien o bien se ha creado a sí mismo. Pero esta última alternativa es imposible, pues o se ha creado antes de existir o bien después. Surge entonces la contradicción, pues si se creó después de existir , nada fue creado porque ya existía; y si lo fue antes, entonces hablamos de la nada, y la nada, nada puede hacer.

30 Idem, p. 40.
31 Idem, p. 39.
32 Idem, p. 41. 
Entonces, debemos concluir necesariamente que nada de lo existente se crea por si mismo; todo cuanto hay en el mundo es necesariamente creado.

Ahora bien, las causas que le han dado origen, en el recuento retrospectivo, son siempre limitadas y, por lo tanto, llegamos siempre a una causa primera.

Por último, es sabido que todos los seres existentes son de naturaleza compuesta y los componentes son necesariamente anteriores. Pero aquello que es la causa inicial de los mismos no tiene causa; lo que no tiene causa no tiene comienzo ni tampoco tiene fin. Se establece, pues, que todo ser compuesto tiene una causa y por lo tanto es creado y no eterno. Entre la creación y la eternidad no hay término medio. Así, todo ser compuesto es necesariamente creado.

Las pruebas de la existencia de Dios son sus obras: la creación del mundo y sus criaturas, en tanto seres compuestos, dan cuenta suficiente de ello. El creador se revela en sus obras.

Habiendo establecido las pruebas de la existencia de Dios, el autor procede a probar la unidad de Dios, examinando si es uno o múltiple.

El análisis de las causas demuestra que éstas son siempre inferiores en número a los efectos que producen y que cada vez que retrocedemos en ellas, éstas disminuyen hasta llegar a la causa única, la causa primera. De esta forma podemos comprender que los seres individuales se agrupan en especies, las especies en géneros, los géneros en categorías (que, según Aristóteles, son diez). Los individuos comprendidos en estas categorías nacen bajo el efecto de cinco causas: el movimiento y los cuatro elementos (fuego, aire, agua y tierra). A su vez, los cuatro elementos se encuentran en dos causas: la materia y la forma y, por último, estas dos nacen de una causa única, la voluntad de Dios.

La unidad divina resplandece por la armonía de sus obras, desde lo más pequeño e ínfimo hasta lo más grandioso. Si hubiese más de un creador, la armonia no se daria. El creador y conductor de tal orden es necesariamente único. La armonía e interdependencia de las partes responden a la voluntad divina.

El mundo, en tanto creado y compuesto, supone un creador, no más de uno; la multiplicidad sería imposible. La sabiduría de Dios se manifiesta en sus criaturas y en la armonía que ellas muestran. Dios, no siendo ni sustancia ni forma, es invisible y solo susceptible de ser conocido por sus obras o por el razonamiento.

Dios en tanto único, es anterior a todo, pues entenderemos por unidad lo siguiente:

El concepto de la unidad es en nuestro espiritu, el de la unicidad pura, de una particularización excluyente de toda composición, de toda suerte de semejanza, multiplicidad, número, unión o separación ${ }^{\ddagger 3}$. 
Dios es, entonces, absolutamente Uno, porque no hay término medio entre la unidad y la multiplicidad; además, lo múltiple es colección de unidades, con lo cual queda establecida la anterioridad de lo Uno. Dios, por lo tanto, no admite ni la sustancia ni el accidente e inconsecuencia, de Él nada se puede predicar: de su naturaleza solo cabe decir lo que no es.

En caso de que hubiese dos o más creadores, lo creado respondería a dos posibilidades: una, que uno de ellos fuese el creador y, en tal caso, la dualidad sería superflua, o bien, que el mundo fuese creado por ambos, lo que significaría que ambos serían incompletos y no tendrían plena potencia.

Dios es Uno, pero se hace necesario distinguir entre lo que es el Uno real y el Uno metafórico. El Uno metafórico es accidental, se usa para nombrar la unidad accidental de una colección. Decimos asi "un ejército", pero "un ejército" está compuesto de muchos hombres; decimos también "un hombre", pero "un hombre" es un ser compuesto de muchos elementos.

El Uno real, en cambio, es aquello que no admite elementos constitutivos. El Uno real abstracto alude a todo comienzo, a todo origen, es la unidad numérica anterior a toda serie. Así decimos: y fue la tarde y la mañana, el dia uno (Génesis 1:5).

Este uno es abstracto, porque no cae en el ámbito de los sentidos, sino en el del pensamiento; es la idea de lo uno. Ahora bien, el uno real existe bajo la forma de lo concreto, es aquello que no puede cambiar ni multiplicarse, ni alterarse, ni cabe atribuirle cualidad alguna de la materia. Es infinito. El uno real es causa de toda multiplicidad, así como el uno abstracto es fuente de lo múltiple.

Dios, por consiguiente, es el uno real, causa del uno metafórico; es el creador de todas las cosas y de su armonia; fuera de Él no hay unidad auténtica. A nada de lo creado puede atribuirse lo Uno real, solo lo Uno meta fórico, pues el segundo, como hemos dicho, procede del primero.

Cabe ahora establecer los atributos de Dios según la razón y según las Escrituras.

Según la razón, podemos atribuir a Dios existencia, eternidad y unidad. Es la imperfección del hombre lo que hace de los atributos de Dios algo múltiple:

La multiplicidad de los atributos no nace de la esencia de Dios, sino de la imperfección del lenguaje humano que no puede agotar en una sola palabra la realidad que quiere ceñir ${ }^{34}$.

Los atributos, según la Escritura, son de dos clases: aquellos que expresan alguna similitud con una forma corporal y que procede de la idea de que el hombre está creado a imagen de Dios y, por otro lado, los atributos que expresan movimiento de actos materiales, actos semejantes a los actos humanos. 
Esta antropomorfización está al servicio de la comprensión:

es necesario entonces que las palabras y lo que ellas traducen sean a la medida de la inteligencia de los hombres a quienes se dirigen ${ }^{35}$.

El hombre inteligente sabrá, para descubrir la verdad y elevar su espíritu, leer el sentido y no solo la forma. Por otro lado,

los antropomorfismos no dañan al hombre razonable, pues él comprende su sentido verdadero. Son útiles al simple, enraizan en su corazón y en su pensamiento el concepto de un Creador al cual hay que someterse ${ }^{36}$.

Pero es necesario, al finalizar este pórtico, decir que, en realidad, de Dios nada se puede predicar, de Él nada sabemos, solo su nombre. Para conocerlo, hay solo caminos: la razón y las Escrituras. $Y$, sin embargo,

el fondo del conocimiento de Dios es saber que uno está en el colmo de la ignorancia respecto a Él ${ }^{37}$,

y que Dios

en la potencia de su gloria es más secreto que toda cosa escondida, más lejano que toda lejanía. La razón revela solamente que Él es. Si intentamos penetrar Su esencia, o atribuirle una semejanza, la existencia misma de Dios se desvanece, pues en este caso la razón tiende a un fin que no puede alcanzar ${ }^{38}$.

\section{SEGUNDO PÓRTICO}

\section{LA CONTEMPLACIÓN DE SUS CRIATURAS}

Una vez establecida la unidad de Dios se hace necesario seguir por el camino trazado, es decir, admirar la sabiduría divina en su creación. Para ello hay que partir por contemplar a sus criaturas. Pero el hombre está cegado a este deber, sumido en sus ambiciones, insatisfecho con sus logros, semejante a un necio que no ve la gracia con que Dios lo colma. Es entonces necesario despertarlo de su ceguera: 
Porque es así, incumbe a los hombres conscientes despertar a los que se encierran a los esplendores de Dios y enseñarles toda la ventaja que tendrían en abrir su espíritu. Se les escapan alegrias inmensas de las que no pueden gozar por incomprensión y desconocimiento de su valor ${ }^{3}$.

Contemplar las criaturas es esencialmente descubrir los rastros de la sabiduría divina impresos en ellas y pesarlos en el alma con todo discernimiento ${ }^{40}$.

Sin embargo, los rasgos de esta sabiduria no son uniformes, pues Dios, en su calidad de ser absolutamente libre, crea, según el tiempo, obras diversas. La diversidad es, entonces, el sello de la Voluntad Creadora.

El contemplar las criaturas es un deber atestiguado por la razón, la Escritura y la tradición. De ellas debemos obtener la prueba de la sabiduría divina. Dios ha dado al hombre discernimiento y con él lo aparta de las bestias; este discernimiento debe usarlo para cumplir el deber de contemplar las criaturas. Si no lo hace, entonces se torna semejante a las bestias.

Ibn Pakuda señala como un deber la contemplación de los signos de la sabiduría divina más cercanos a nosotros, es decir, los signos que están presentes en el seno de las criaturas mismas:

Debemos contemplar todas las cosas. Pero si el objeto nos conmueve más, tómase más urgente nuestro deber. La sabiduría menos lejana de nosotros y la menos velada, es aquella cuyas huellas aparecen en el hombre ${ }^{4 !}$.

La maravilla de la creación del hombre es, pues, lo más cercano a Díos. El hombre es su criatura dilecta. Por eso, contemplando y maravillándonos ante el hombre, descubriremos y comprenderemos la divinidad de Dios. La perfección del funcionamiento del cuerpo y la finalidad de sus funciones nos revelan la voluntad divina. Pero, principalmente, la sabiduría divina se muestra en la razón y el entendimiento con que nos ha dotado, separándonos de las bestias.

La gran bondad que esto significa nos obliga a la sumisión delante del Señor. A ello se suma el privilegio de la escritura que hace posible la transmisión y la perpetuación de la tradición, del pensamiento de los antiguos, como también de los contemporáneos. Pero sin duda es la Torá, el don más precioso, la prueba más brillante de la existencia de Dios.

Por último, hemos de considerar todo lo existente que hace posible la subsistencia del hombre: todo permanece y se remueva por la voluntad del Señor en favor nuestro.

Pero, -dice ibn Pakuda-, debemos tener cuidado, pues hay causas corruptoras de la contemplación de las criaturas, siendo la principal, entre ellas, un corazón orgulloso. 
Aquel cuyo corazón es altivo, es la abominación del Sef̃or ${ }^{42}$

(Proverbios 16:5).

El hombre en su finitud debe estar siempre maravillado y temeroso ante la infinitud de Dios. Todo cuanto logremos saber, solo será una prueba de lo poco que sabemos respecto de Dios. Solo un corazón puro es agradable al Señor.

\section{TERCER PÓRTICO}

\section{LA SUMISIÓN A DIOS}

El deber de someternos a Dios es semejante al deber de devolver el bien a quien nos lo hace. Como el agradecimiento y gratitud que se siente hacia un individuo que nos hace un bien, así y más aún, debe ser el agradecimiento para con Dios.

Debemos considerar ante todo que la beneficencia humana es egoísta, ya que persigue la felicidad, el reconocimiento o, incluso, solo el interés. Con mayor razón, entonces, debemos someternos a Dios, pues sus beneficios son permanentes hacia nosotros, la más débil de las criaturas.

Cuando el hombre hace el bien, está movido por la necesidad. Lo que da, en rigor no le pertenece $y$, aun, de todas formas lo mezquina, lo mide y no lo entrega permanentemente y lo da por interés: como el padre, que cuida a su hijo guiado por sentimientos naturales, o como el amo, que cuida a su esclavo para proteger su interés, o como el rico que es generoso con el pobre a fin de ganar el cielo, o como el filántropo que está guiado por amor a la gloria y el deseo de recompensas terrenales. No obstante esto, nos está mandado ser agradecidos con nuestros benefactores. Entonces, mucho más debemos agradecer y someternos a Dios, porque Él nos colma de bienes gratuitamente.

Visto lo anterior, el hombre, reconociendo la superioridad, omnipotencia y la perfección de Dios, le debe sumisión absoluta, en virtud de que sus dones son enteramente gratuitos y permanentes para con una criatura tan débil como lo es el hombre, que solo se diferencia de las bestias por su capacidad discursiva.

La razón exige al hombre que se someta a Dios, pero entre el momento en que nace y el tiempo en que llega a usar su inteligencia, el hombre no debe permanecer sin religión. Hay que advertirle para que así lo entienda. Esta advertencia es, por un lado, innata, pues está implantada en su inteligencia; pero, por otro lado, es tradicional, ya que está dada por la Torá, la enseñanza, transmitida a los hombres por los profetas, con el objeto de enseñarles el camino de sumisión. 
La necesidad de esta doble advertencia es fundamental en la medida en que la razón es débil y que todo lo que la rodea tiende a atrofiarla y solo la Torá puede fortalecerla.

¿Por qué? Porque el hombre, en tanto ser constituido por dos sustancias, -alma y cuerpo-, tiende a fines opuestos.

El cuerpo tiende a la concupiscencia, lo que asegura la perpetuación de la especie y hace al hombre trabajar por las cosas materiales. El alma, por su parte, tiende al discernimiento perfecto, desdeña este mundo y trata de elevarse hacia el mundo superior. Pero, desafortunadamente, la concupiscencia en este mundo se ve fortalecida en extremo y, por el contrario, la razón es casi atacada por todo y necesariamente tiende a debilitarse. La Torá es el remedio, porque ella nos purifica mediante sus prescripciones, porque a su contacto la razón se desenvuelve, se aclara y se ilumina, y saca al hombre de la locura que le impide ver las cosas en su realidad:

Someterse a Dios. Tal es la intención y el fin de la creación del hombre en este mundo ${ }^{43}$.

La sumisión a Dios debe entenderse como una prosternación del hombre ante el dispensador de todos los dones, en reconocimiento perfecto de sus gracias.

Ella, nos dice ibn Pakuda, también es de dos tipos: una proviene del temor de Dios, otra, de la esperanza. Ésa nos está dada por la Torá y se debe a la promesa de un premio o un castigo. La otra es una alabanza y está implantada en la inteligencia. La primera es escala para la segunda y esta última es más agradable a Dios, según se desprende de las siete razones que pasamos a enumerar:

1) La sumisión que surge de la Torá puede ser celestial, pero también puede que se ejerza por la voluntad impía de obtener honores. En cambio, la que nace de la razón está por entero consagrada a la alabanza de Dios.

2) La primera es en espera de una recompensa. La segunda es generosidad del alma, su compensación es la gracia que el alma encuentra ante Dios.

3) La primera es un requerimiento exterior. La otra se oculta en el corazón.

4) La sumisión que nace de la Torá es una introducción a la sumisión que solicita la razón.

5) Las órdenes de la Torá son limitadas, -613 preceptos-; los imperativos de la razón, en cambio, son infinitos y nacen de los deberes del corazón. Por ende, la sumisión también debe ser infinita porque infinitas son sus gracias.

6) Todo hombre puede cumplir con los preceptos de la Torá, pero solo con la gracia de Dios podemos cumplir con la sumisión que ordena la razón, porque el hombre es muy débil para alcanzarla por sí solo. 
7) Ningún hombre puede jactarse de estar a salvo del pecado y la concupiscencia, ya que solo lo logrará cumpliendo con la Torá. En cambio, a quien se entrega a la alabanza que exige la razón, ningún mal puede alcanzarlo.

Por su parte, la excelencia de la Torá también se puede explicar mediante un número igual de motivos ya que la Torá es una guia, una condición previa a la razón hasta que ésta se fortalezca:

1) La doble tendencia del hombre lo impele a ir en sentidos contrarios y ninguno de ellos es bueno. La Torá, en cambio, dirige nuestras vidas y establece el justo medio entre ambos caminos.

2) La advertencia de la razón es general, no expresa detalles. Los detalles necesarios respecto del cómo, del cuándo y del dónde, son entregados por la Torá.

3) No todos los hombres pueden recibir la advertencia de la razón, porque no todos ellos están igualmente dotados intelectualmente. La advertencia de la Torá es un llamado para todos los hombres que están sometidos a ella. La razón del hombre es más débil y varía en ciertos estados; la Torá, en cambio, no varía jamás, permanece siempre.

4) Los actos de sumisión obligan mayormente al pueblo judio, pues él es el elegido de Dios, una nación santa.

5) La Torá es la introducción para la advertencia de la razón, es una guía indispensable para el hombre en toda época de su vida.

6) La Torá impone leyes por autoridad y otras se arraigan en la razón, pero estas últimas no podrían ser comprendidas por los intelectos menos dotados. Por eso, ella impone una ley única para todo hombre y cada uno, en virtud de sus capacidades, sabrá entender de donde proviene: el hombre inteligente sabe ver en ellas el fondo de fe y razón, el ignorante las aceptará porque está revelado.

7) Al ser el pueblo judío un pueblo elegido, su deber se torna más imperioso, como lo sería comprender que todo privilegio implica un deber que debemos cumplir. El no hacerlo nos tornaría semejante o peor que las bestias; perderiamos nuestra dignidad humana.

La advertencia de la Torá distingue varios grados.

Lo primero es comprender la definición de este concepto:

La advertencia de la Torá es una revelación que se dirige a un hombre para hacerle conocer los actos de obediencia que agradan a Dios, a fin de compensarlo en este mundo y coronarlo en el más allá con generosidad, magnificencia y bondad ${ }^{44}$. 
La Torá distingue tres categorías de actos:

La primera la constituyen los actos prescritos, que se dividen en deberes del corazón y deberes del cuerpo.

La segunda, los actos prohibidos (que comportan la misma división anterior).

La tercera, los actos lícitos. Estos pueden ser moderados, excesivos o defectuosos.

Todos ellos dicen relación con la vida del hombre y su comportamiento frente a Dios, pues todos los actos del hombre se inclinan al bien o al mal.

Por otro lado, los hombres consagrados al estudio de la Torá se distribuyen en diez grados, desde aquel que solo comprende su sentido literal, hasta el que ha heredado su ciencia de los profetas y conoce la palabra de Dios en forma perfecta, completa y total: son los doctores de la gran asamblea.

A estos diez grados corresponden diez peldaños de adeptos de la Torá, repartidos según su fe y su manera de servir a Dios:

1) los que consideran la Torá como una institución política;

2) los que no rechazan sus virtudes, pero dudan constantemente;

3) quienes creen en la Torá y la religión, pero no creen en una recompensa en la vida futura, solo creen en la de este mundo;

4) los que creen en la Torá y sus retribuciones, pero se inclinan a amar el mundo y sus posesiones. La religión no habita en sus corazones;

5) los que creen en una recompensa en el Más Allá, pero también aman la recompensa de este mundo. Cumplen sus deberes en vista de esto;

6) los que esperan de Dios una recompensa terrenal inmediata;

7) los que esperan de Dios una recompensa terrenal y una celestial;

8) los que actúan por temor al castigo divino, terrenal y celestial;

9) los que creen en Dios y en la Torá, esperan en la recompensa terrenal y celestial con intención pura, pero no se cuidan de la corrupción que se instala en los corazones sin que el hombre se dé cuenta;

10) por encima de estos están los que adoran a Dios gratuitamente, creen en la Torá, así como en la recompensa en los dos mundos y aspiran a Dios con todos sus deseos, porque conocen su camino.

El llamado de la razón puede representarse como un diálogo entre el alma y la razón, en donde la razón despierta al alma para que se entregue a la adoración perfecta de Dios, para que se eleve en la elección de la justicia, la reprobación de la mentira y la iniquidad. Se dará cuenta de que Dios no necesita de su adoración y entonces la razón le mostrará qué es lo necesario para acercarse a Dios. 
El deber de sumisión debe extenderse, debe crecer en proporción a los beneficios universales de los que somos beneficiarios. Los hombres, en la medida en que se dan cuenta que son los mayores beneficiarios de entre las criaturas, deben ser los mayormente sometidos. Así también ocurre con los pueblos y las naciones.

Hay grados menores de sumisión, pero el hombre jamás debe medir el grado de su entrega a Dios. Por el contrario, debe aspirar siempre a una práctica superior de las virtudes del alma. No debe jamás menospreciar a quien ha sido abandonado por Dios, a quien ya no goza de su gracia, pues no es mérito del hombre dar ni quitar nada: todo mérito es de Dios.

El hombre parece estar sujeto a la libertad o al determinismo y esta contradicción que aparece en la Torá es imposible de resolver. La única respuesta posible a este problema, es una completa confianza en Dios, pues Él elige lo mejor para nosotros. Solo Él es justo y quien se empecina en resolver la contradicción en forma más profunda, está más cerca del pecado. Dios siempre tiene razón contra el hombre, el hombre jamás contra Dios. El hombre es demasiado débil e ignorante de los misterios de la creación.

El misterio de la creación del hombre en este mundo se relaciona con su destino de ser extranjero en el mundo. En este sentido, no debe apegarse a este mundo, sino proyectarse al otro que es más real y verdadero. El misterio de la existencia es que Dios nos ha creado de la nada y quiere conducirnos al grado de los elegidos, quiere nuestra felicidad, porque nos ama gratuitamente. Para esto debemos despojarnos de nuestra imperfección original, para poder ser dignos de y ante Dios. Cuando llegue el momento final, será revelado el destíno de las obras y elecciones que hicimos en este mundo.

El ejercicio de las virtudes tiene por finalidad:

1) estar confusos ante los dones de Dios y sus castigos y reprensiones;

2) ser audaz con los criminales para impedir el mal y ordenar el bien;

3) ser furiosos con los que se desvían de la verdad, pero agradables con los justos;

4) ser misericordiosos con los pobres y con los humildes, con los enfermos y los ascetas, y suaves con el que está en desdicha;

5) ser orgullosos y altaneros contra los que reniegan de Dios;

6) ser humildes ante los piadosos, puros con los que merecen nuestro reconocimiento;

7) amar a quienes siguen nuestros pasos, ellos serán la alegria y regocijo;

8) no apresurarnos a satisfacer nuestros instintos carnales, pues sus placeres son fugitivos. En este mundo prevalece su marca y en el del más allá su castigo. 


\section{CUARTOPÓRTICO}

\section{ELABANDONO DE DIOS}

El abandono es la virtud más necesaria para la sumisión al Señor: Quien confía en Dios y abandona toda la inquietud por las cosas del mundo, gana la paz del alma. En cambio, aquél que confía tan solo en sí y en sus fuerzas es abandonado por Dios.

El oro y la riqueza a menudo acarrean desdicha y preocupaciones, por lo tanto no hay que envidiarlos. Además, estos bienes son fugaces y después, de ellos nada queda. El abandonado, en cambio, siempre es rico pues se entrega en todo a Dios.

El abandono conduce a servir solo a Dios y a olvidarse de las preocupaciones que acarrean los hombres, a volverse invulnerable contra los avatares de su suerte:

El completamente abandonado siempre está seguro de encontrar su subsistencia, pues no vive solamente de pan ${ }^{45}$

(Deuteronomio 8:3).

En cambio, el que no se abandona está librado a toda suerte de sufrimientos:

La utilidad del abandono es grande ante Dios. Si el abandonado es rico, cumple sus deberes para con Dios y para con sus semejantes con prontitud y devoción. Si es pobre, considera la pobreza como el más precioso de todos los dones; ella alivia el cumplimiento de sus deberes para con Dios y los hombres, le ahorra los cuidados y las penas que habria tenido administrando su fortuna ${ }^{46}$.

El abandono es lo que por esencia da la paz al alma. El que se abandona debe apoyarse sobre aquello en que pone su confianza. Debe tener la certidumbre de que su apoderado hace lo que es bueno y conveniente en los negocios que le remite, con poder y pleno conocimiento de los que contribuye a su felicidad ${ }^{47}$.

Las causas determinantes del abandono en las criaturas deberian ser que un hombre encuentre en otro entera simpatía y solicitud generosa, amor, agasajo y potencia, un conocimiento pleno de todo su ser, y de lo que es bueno o malo para él, debe conocer lo oculto y lo invisible, debe ser el único que gobierne la vida del abandonado, desde el origen hasta el fin. El abandonado debe estar tan entregado que nadie pueda hacerle bien o mal. Por último, la criatura en quien se abandona debe ser absolutamente generosa, de un infinito amor para quien lo merece y para quien no. 
Pero basta un pequeño análisis para darnos cuenta de que ninguna criatura cumple con estos requerimientos: un amigo se cansaría al tener que estar mostrando siempre y en todo momento fortaleza, además sería impotente para llenar ciertas necesidades del abandonado; todo hombre tiene un conocimiento limitado de su propia realidad, cuánto más respecto a la del otro.

Sin embargo, existe un ser que posee todas las condiciones para el abandono: es Dios, nuestro Creador; Él todo lo sabe y jamás se cansa, Él tiene la potencia y el conocimiento, la plenitud y la gloria y protege al hombre desde el origen hasta el fin de sus días.

Las causas determinantes del abandono en Dios consisten en que el hombre debe considerar con evidencia que Dios reúne todas las virtudes para abandonarse a Él. Dios es misericordioso con el hombre más que con cualquier otra criatura, conoce la manera de salvarlo, pues es su obra; conoce el desarrollo de su vida, las enfermedades que lo aquejan y la forma de curarlas. La palabra de Dios es todopoderosa, nada en el mundo se cumple sin su mandato. Dios todo lo ve y todo lo sabe. Nadie tiene poder sobre otro, si no es Dios mismo quien se lo ha entregado:

Cuando el hombre comprenda que ninguna criatura puede hacerle bien o mal sin la voluntad permisiva del Creador, cesará de temerlas o de esperar nada de ellas, para abandonarse solamente a Dios ${ }^{48}$.

Debemos conocer el amor de Dios, solo con mirar la abundancia de sus dones, gratuitos por añadidura, para nosotros que no tenemos ningún mérito. También debemos conocer que la voluntad de Dios es inalterable: el orden del tiempo, las estaciones y la productividad o esterilidad de la tierra y los animales son mandato divino y nada puede hacerse contra eso.

Cuando estamos ciertos que Dios conoce lo íntimo de nuestro corazón, no podremos permanecer en un abandono solo de palabra, sino que deberemos comprometer en ello nuestra conciencia. Solo Dios debe ser objeto de nuestro abandono, nada más. Debemos estar y ser atentos y celosos en el cumplimiento de nuestros deberes religiosos y guardarnos de lo que Dios ha prohibido para llegar a obtener su gracia.

El último pensamiento que hace nacer en nosotros la certidumbre del abandono en Dios es considerar el devenir del universo: éste fue creado por la voluntad de Dios y fue también Dios quien creó las causas intermedias para que siguiera existiendo en completo orden y armonía. Es así que debemos considerar que todas las causas provienen de Dios y que Él posibilita el paso de la potencia al acto:

Le ha parecido útil al Creador dejar al hombre obrar y recurrir a causas intermedias para satisfacer sus numerosas necesidades. Por otra parte Dios quiere probar la fidelidad o la rebeldía del alma, en el camino de la sumisión ${ }^{49}$. 
Si nos mantenemos firmes en nuestra sumisión y alejados del pecado -dice ibn Pakuda-, seremos preservados por Dios y no nos tentarán ni el mal ni los sortilegios del mundo.

Sin embargo, numerosas veces podemos ver a un justo siendo castigado y a un malvado gozando de la felicidad. Eso no debe preocuparnos, pues responde a la voluntad del Señor: el justo puede estar pagando pecados anteriores o estar ganando con ese castigo una recompensa celestial o ser probado por Dios con la miseria o la enfermedad para hacer resaltar su amor. El malvado puede estar siendo recompensado por méritos anteriores, o bien que su fortuna vaya a ser la principal causa de su desdicha, aunque también Dios puede esperar la conversión de un malvado. Pero sin duda, de todo esto lo más importante y lo más cierto es que

los misterios pertenecen al Señor y las evidencias a nosotros y nuestros hijos ${ }^{\mathrm{sa}}$ (Deuteronomio 29:28).

Por último, todos tenemos inclinación por algún tipo de oficio, liviano o pesado, intelectual o manual, según nuestras capacidades. Pues bien, debemos trabajar con el cuerpo y con el alma, recurriendo a causas segundas para nuestra subsistencia pues

nuestro abandono en Dios debe ser perfecto. Nuestro recurrir a las causas segundas no engaña en nada esta quietud, cuando espíritu no ve más que a Él sólo. El hombre no debe creer que su subsistencia depende de una causa determinada e irremplazable. Ha de abandonar su vida en el Señor y reconocer que a la vista de Dios, todas las causas valen ${ }^{3 !}$.

El dominio del abandono es pues, esencial:

el creyente debe abandonarse al Creador en las cosas de este mundo como en las del más allán.

El hombre totalmente abandonado debe hacer entrar en cada plano de su vida el abandono en el Señor y solo en Él.

En lo tocante al cuerpo y a nuestra subsistencia, debemos abandonamos en Dios, pero sin dejar de recurrir a causas intermedias que nos ayuden a satisfacer nuestras necesidades de comida, vestido y salud, pues ellas en sí mismas no son ni útiles ni nocivas; son la voluntad del Señor y nuestro trabajo los que hacen de ellas instrumentos para el bien o el mal. Por otro lado, tampoco está permitido arriesgar nuestra vida gratuitamente y mucho menos quitárnosla por nuestra propia mano: éste es el mayor pecado que se puede cometer, pues está lo más cerca que es posible de nosotros. 
En lo tocante a nuestros negocios, cualquiera sea su indole, debemos abandonarnos en Dios, pues es Él quien dispensa el éxito o el fracaso de ellos. Debemos multiplicar nuestros esfuerzos, pues todo excedente llegará sin penas ni fatigas. En toda circunstancia que nos encontremos, de abundancia o de miseria, debemos pensar que es Dios quien lo dispone así, porque solo Él sabe lo que es bueno.

En lo tocante al cuidado de nuestra familia, nuestros hijos y parientes, debemos pensar y conducirnos como si fuésemos extranjeros y solitarios, así como lo es el alma en este mundo material, y considerar que los lazos que unen a las personas son transitorios:

Ningún parentesco le servirá de ayuda, ningún hijo, ningún compañero en la muerte ${ }^{33}$

Y más aún, debemos pensar que todo lazo es molesto y que

la soledad es una gracia divina ${ }^{54}$.

El totalmente abandonado cuida de sus parientes y les enseña el camino hacia el Altísimo, pero debe abandonar sus preocupaciones en Dios, no debe esperar de ellos ninguna retribución, ni sentir que ellos le adeudan gratitud, sino solo cumplir con las órdenes del Señor.

En lo que toca a los deberes del corazón y del cuerpo que solo afectan al individuo, el sentido de su sumisión o rebelión solo es posible teniendo en la conciencia estos tres factores: libre elección, voluntad intencional y esfuerzo manifiesto.

No podemos en esto abandonarnos en Dios. El verdadero abandono requiere de una voluntad, y para ello Dios nos ha dotado de la libertad de elegir. No ocurre lo mismo con el culto, en donde el Señor nos ha revelado claramente el camino a seguir por medio de las prescripciones de la Tora.

Referente a los deberes del cuerpo, que traen la felicidad a los demás, como la caridad y el deber de honrar a los padres, deben ser cumplidos con intención pura, solo por sumisión al Señor y no por afán de ganar renombre.

Nuestros actos son recompensados en la tierra como en el cielo, pero nosotros desconocemos la índole de tales recompensas o castigos y la Torá nada nos dice al respecto, pues es dominio de Dios. Los actos aparentes, surgidos de los deberes del cuerpo, son recompensados con evidencias, los actos ocultos, los que surgen de los deberes del corazón, Dios les reserva una recompensa y beatitud secreta, en el Más Allá:

El abandono en Dios, para su retribución en esta vida o en la futura, consiste en creer en la justicia divina, en tener una fe perfecta, la fe de Abraham que le fue adjudicada en 
justicia (Génesis 15:16). Es una confianza irreducible en el triunfo de la divina bondad sobre la tierra de los vivientes ${ }^{5 s}$

(Salmos 27:13).

Todo aquel que se somete y se abandona en Dios y busca sus caminos, será recompensado en el más allá por Dios. Esta clase de hombres está marcada por el amor a Dios, la sumisión y la paciencia. Ellos prefieren morir esclavos del Señor, que alejarse de él.

El totalmente abandonado se distingue de los otros en que alaba al Señor en la felicidad y en la desdicha. Tiene en paz su alma, pues confia su suerte al Señor; solo se abandona en Dios y considera las causas intermedias solo como instrumentos para servir a Dios; no espera de ellas ningún bien ni ningún mal. Dedica todo su tiempo a lo que es agradable a Dios sin mezquinar nada. Se ocupa de las cosas de este mundo solo con el fin de recorrer bien provisto el camino futuro.

Todos los hombres lo aman y confian en él, pues él no espera nada de los hombres, ni bien ni mal. Nunca se inquieta, porque confía su suerte y su pan cotidiano al Señor. Solo se angustia cuando es negligente con los deberes del corazón.

En cambio el que no se abandona, sufre los avatares de su suerte con mayor padecimiento pues se confía en las causas intermedias, en la fortuna y en la adversidad. En la fortuna, porque nunca está satisfecho y en la adversidad, porque se desespera por las circunstancias, se irrita contra los designios del Señor, su alma nunca está en paz y su vida es una larga desdicha. aÉl:

Señala $i b n$ Pakuda que las criaturas no pueden exigir nada al Creador antes de someterse No seáis como esclavos que sirven al amo para recibir salario ${ }^{56}$.

El insensato que quiere pedir una garantía a Dios, lo mismo que un comerciante pide una prenda por el crédito otorgado, incurre en un grave error, pues el mismo desconoce el número de sus días:

La deuda del hombre para con Dios es tan grande que si la humanidad entera cargara con ella jamás llegaria a compensar el más pequeño de sus beneficios ${ }^{57}$.

El deber de sometimiento y el culto religioso están ligados al tiempo, a nuestro tiempo presente. Exigir de Dios la subsistencia para el tiempo futuro es una necedad, pues aún no existe y quizás nosotros mismos no lleguemos a ese tiempo. Exigir garantía o prenda a nuestros prójimos es aferrarse a este mundo y los bienes materiales, y es bien sabido que la mucha 
riqueza suele ser también mucha desdicha y preocupaciones. En nuestra condición de seres finitos e imperfectos, estamos endeudados con Dios por los bienes con que nos colma, de tal forma que jamás podremos saldar la deuda. Ni aun el sabio puede hacerlo sino con la ayuda de Dios.

Las causas corruptoras del abandono son producto del desconocimiento, porque quien no conoce a Dios e ignora los beneficios con que nos favorece, no puede abandonarse a él. Lo mismo ocurre para quien no comprende las órdenes de la Torá.

También debemos considerar que toda causa que se acerca hacia la causa primera tiene más poder que la cercana a nosotros, pues se encuentra más cercana a la voluntad de Dios. Conviene, por lo tanto, dejar de lado las causas intermedias y más cercanas a nosotros y abandonarse al Altísimo, príncipe de toda causa.

Mientras más ciertos estamos de la imperfección de todas criatura, más se consolida el abandono en Él. Lo mismo ocurre mientras más ascendemos en el conocimiento de Dios: aceptaremos entonces en lo más profundo de nuestros corazones las decisiones de Dios. Cuando lleguemos al punto más alto, comprenderemos la intención de haber sido creados, reconoceremos otro mundo, eterno, despreciaremos el mundo material y buscaremos solo a Dios.

\section{QUINTO PÓRTICO}

\section{LA UNIDAD DEL ACTO}

Luego de haber examinado el abandono en Dios, corresponde analizar las modalidades del acto de sumisión. En la realización del acto inciden, fundamentalmente, la limpidez de conciencia y la nitidez de corazón.

La unificación de nuestros actos en Dios es la intenciỏn, lo mismo manifiesta que secreta, de realizar los actos de sumisión en Su nombre, para buscar su aprobación con exclusión de la de las criaturas ${ }^{5 B}$.

Las condiciones de existencia para la unificación de nuestros actos en Dios constituyen todos los deberes analizados precedentemente en los pórticos de la Unidad, el Abandono y la Sumisión. El cumplimiento de lo que allí se señala, cuando está enraizado en un corazón puro, lleva a un camino que no se aparta de Dios. 
El dominio de la unificación del acto corresponde a los deberes del cuerpo, pues son éstos los visibles y los únicos posibles de ser falseados; en cambio, los del corazón, son inescrutables a los ojos humanos: solo Dios y cada hombre sabe lo que hay en su corazón. Entonces, los deberes del cuerpo pueden ser usados para buscar la alabanza de los hombres y no la de Dios.

Es preciso analizar las causas corruptoras de la unificación. Ellas son las que tienen su origen en el desconocimiento de Dios, de Su gracia y de la Torá. También arraigan en la pasión que hace que el hombre se apegue a este mundo.

El autor distingue tres clases de hombre: el ignorante, el idólatra y el creyente hipócrita:

El ignorante es aquel que puede engañarse y no saber reconocer a su verdadero Señor. El idólatra es quien se entrega a sus ídolos y no se oculta, por ello es fácil distinguirlo y apartarse de él; adora la nada y en esto no se opone a Dios. Por último, y en el grado más bajo, está el creyente hipócrita que está sometido a Dios solo en apariencia; es, por lo tanto, dificil distinguirlo porque en su corazón, semejante a una plaga oculta, se esconde y acecha mucho mal:

El tonto no teme el pecado y el ignorante no puede ser piadoso $(A v o t 2: 5)^{59}$.

La pasión por su parte, nos hace apegarnos a este mundo, nos hace dudar del deber de Sumisión y Abandono, e incluso nos proporciona argumentos lógicos con los cuales rechazarlos.

Debemos analizar cuáles son los ataques de la pasión para poder ponerle los remedios necesarios. El mayor enemigo que nos acecha es la pasión, ella habita en nuestro ser y está presente en todos los planos de nuestra existencia y se presenta con los más atractivos aspectos solo para jugar en nuestra contra y conducirnos a la muerte. Si no se le opone resistencia, seremos fácilmente su presa, pero si, por el contrario, armados con la razón sabemos oponernos a ella y ser perseverantes en su contra, con la gracia de Dios seremos benditos.

La principal duda que la pasión siembra, es a partir de la preeminencia del cuerpo sobre el alma; pues juzga que con su muerte, también el alma es aniquilada. Con esto nos arrastra a la búsqueda del placer y de lo fugitivo: un análisis a la luz de la razón y de la Escritura, -señala el autor-, refutará ampliamente esta opinión.

En cuanto a nuestro deber de sumisión, tratará de hacernos creer que no es necesario obedecer a nadie sino cuando nos conviene. Si analizamos lo dicho en los pórticos precedentes, vemos que Dios no tiene necesidad ni de culto ni de nosotros. Por el contrario, somos nosotros los infinitamente necesitados del Señor.

La pasión atacará también a los Profetas y a las Escrituras; querrá también ir en contra de la tradición que ellas implican. Debemos saber contestar que los pilares fundamentales, que son la Biblia y la razón, serían débiles sin el apoyo de la Tradición. 
Querrá también arrastramos al orgullo intelectual y a la búsqueda de las alabanzas de los hombres, al manejo del lenguaje y de las ciencias. Pero con la guía de la razón podremos ver que toda ciencia que se aparte de la Torá es inútil:

Lo superfluo es un bien si está dado por Dios y utilizado con fines convenientes, pero si ha de empañar la paz del corazón y acrecentar la preocupación de nuestra alma, vale más contentarse con el pan dejando de lado el resto ${ }^{69}$.

Los hombres seremos presa de la pasión en la medida de nuestra inteligencia. Aquel que se envanece y se confía solo en su inteligencia es el más expuesto, pues desprecia la ayuda de la Tradición, la Escritura y los Maestros.

La pasión querrá incluso alcanzar al hombre santo, que se ha entregado con corazón puro al abandono y la sumisión; querrá hacerlo desistir de sus deberes, proponiéndole ocuparse de las alabanzas mundanas y, estando en oración, intentará hacerlo divagar en otros pensamientos que no sean Dios y tratará de que deje el momento de sumisión para el último día de su existencia. Del mismo modo, querrá que recrimine al pecador en público y, por último, trabajará para sembrar la envidia en el corazón del santo, frente a otro más santo que él y que se somete con mayor entrega. Pero el hombre verdaderamente abandonado tiene el corazón tranquilo, no se preocupa de nada, excepto de Dios, y a todos estos requerimientos de la pasión sabe contestar así: se debe ser insensible tanto a la alabanza de los hombres como a su crítica; solo el juicio de Dios importa. El castigo de Dios será inmenso si lo alabamos con la boca mientras el pensamiento está en otra parte. Desconocemos el último dia de nuestra existencia, por lo tanto no nos está permitido postergar nuestros deberes para un día incierto. El corazón del hombre solo lo conoce Dios, por lo tanto, ninguna criatura puede enjuiciar a otra. Por último, sabrá contestar que frente a un hombre que alaba a Dios con el corazón más puro que el propio, solo cabe amarlo más por ello.

Ante la asechanza de las causas corruptoras y de la pasión, existe la necesidad del control y del dominio del pensamiento. Es necesario ser vigilantes con nuestros pensamientos, pues todos nuestros actos buenos y malos, provienen de alli. También debemos vigilar nuestro corazón, pues allí se engendra la rebeldia, y estar atentos y cautelosos a las causas corruptoras que amenazan nuestro verdadero abandono y sumisión. Purificar nuestros actos antes que multiplicarlos, ése es nuestro deber. 


\section{SEXTOPÓRTICO}

\section{LA HUMILDAD}

Luego de haber visto lo que es el orgullo, principal sentimiento que nos impide el verdadero abandono y sumisión, veremos cuál es su contrapartida: la humildad.

La humildad es el fundamento del estado de servidumbre ${ }^{61}$,

y es buena porque libera al hombre de todos los sentimientos que niegan a Dios, como la soberbia, la arrogancia, la sobrevaloración de sí mismo, y todos los frutos del orgullo.

La humildad es la virtud por la cual el alma se humilla, se despoja y se estima en poca cosa. Los signos de ella aparecen sobre todo en el cuerpo y son: dulzura del lenguaje, voz baja, contención probada en el momento de la cólera, ausencia de toda venganza aun cuando se tenga en poder para llevarlá a cabo ${ }^{62}$.

El autor enseña que hay diferentes clases de humildad; ellas son:

1) La humildad que poseen algunos hombres que en nada se diferencia del servilismo de las bestias.

Solo por convención se la llama humildad. Es, en verdad, una impotencia que esclaviza y que impide encontrar una salida a la condición de miseria. Por el contrario, la verdadera humildad es intrepidez del alma.

2) La humildad social, es de indole jerárquica.

Es aquella que muestra el débil frente al poderoso, es la humildad del hombre que es incapaz de encontrar por sí mismo el verdadero camino y se prosterna frente al maestro que puede guiarlo. Esta humildad no es todavia la verdadera, pues todo lo que está bajo el dominio de otro puede cambiar su estado, es decir, el deudor puede pagar su deuda y el prisionero recobrar su libertad. Es, por lo tanto, una humillación pasajera.

3) Existe, por último, la verdadera humildad, la que se impone a todos los hombres delante del Creador, en todo tiempo y lugar.

Es de esta última, de la verdadera de la que ibn Pakuda se va a ocupar en los capítulos siguientes:

Existen causas determinantes de la humildad. En primer lugar está el sufrimiento que padecemos y que nos hace pasar del orgullo a la humildad. Por ejemplo, en el trance de una 
enfermedad, la miseria o la desdicha, el sufrimiento surge de la impotencia de cumplir con nuestros deberes y compromisos. También existe la humildad del arrepentido. Finalmente, está la humildad que surge del temor a la muerte y la certeza de un juicio final y eterno.

El dominio de la humildad nos conmina a ser humildes con todos nuestros semejantes, más aún, ante al justo y al sabio. Debemos ser humildes cuando recibamos alabanzas, no envanecernos y recordar nuestros pecados. Debemos ser humildes delante del Señor, cuando meditemos que somos los beneficiarios de sus dones y mucho más, cuando hemos sido favorecidos con la abundancia, pues mayor es nuestra deuda.

Los medios de adquirir la humildad y hacer más fácil el camino es tener presente las siguientes meditaciones:

1) El origen de nuestro ser es miserable e impuro; somos el fruto de una gota de espermios unida al óvulo y alimentados de sangre, mientras permanecemos en el vientre. Al nacer y durante nuestra infancia somos débiles y luego, al llegar a la vejez, solo cabe esperar la muerte. La condición miserable de nuestro ser debe ponernos en contrición delante del Creador.

2) Somos cautivos en este mundo. Semejante a un encadenado, estamos sujetos al hambre, a la sed, al frío y al calor y solo la muerte puede liberamos de esta prisión. La humildad surge entonces de nuestra impotencia delante del Creador.

3) Si pensamos en que la muerte surge bruscamente y rompe con todos los lazos que nos atan a este mundo y que nuestro cuerpo se pudre en la tierra, entonces, frente a esta corrupción, es imposible no ser humildes y prosternar el alma.

4) Pensemos en nuestra manera de conducirnos, en la imperfección de nuestro sometimiento, y nos humillaremos teniendo en cuenta los pocos argumentos que tendremos cuando llegue el juicio final.

5) Si contemplamos la creación con todas sus maravillas y la pequeñez de nuestro ser ante el orden celestial, si pensamos en los hombres y las criaturas más elevadas que nosotros y que se entregan con mayor perfección al Señor, como los profetas, los santos y los ángeles, cómo no entregarnos a la humildad al pensar que aun en nuestra pequeñez, Dios se acuerda de nosotros.

6) Al revisar lo que las Escrituras dicen respecto del castigo prometido a los orgullosos, el temor hará surgir humildad en nuestro corazón.

7) Por último, pensemos que la fortuna de los hombres y de los reinos, tal como viene, se va y que en su lugar se instala el dolor. Pensemos entonces en el único remedio para cualquier dolor: la muerte. La humildad se impondrá mientras estos pensamientos nos acompañen:

No temáis, proclama Moisés sobre el Sinai, que para probaros vino el Señor y para que Su temor esté en vuestra presencia, para que no pequéis (Éxodo, 20:20). Los doctores dicen: Considera tres cosas y no pecarás más: Sabe de dónde vienes, a dónde vas y delante de quién deberás rendir cuentas y justificarte. ¿De dónde vienes? de una gota 
nauseabunda, ¿A dónde vas? al polvo la suciedad, la podredumbre. ¿A quién deberás rendir tus cuentas? al Rey de los Reyes, al Santo bendito sea $(A v o t 2: 1)^{63}$.

Visto lo anterior, debemos saber que el conocimiento de Dios a través de la Torá nos dará las reglas para cumplir con la humildad.

En primer lugar, debemos arrancar de nuestro corazón el afán de venganza y conducirnos siempre con dulzura. Debemos aprender a hablar bien y no mal de nuestros semejantes. Debemos conducirnos humildemente tanto en nuestros asuntos públicos como privados.

La humildad nos hace desear las cosas del mundo futuro y sufrir por la incapacidad de ser un fiel servidor de Dios y de nuestros semejantes. Al hombre humilde le bastan los medios de que dispone para su subsistencia, pues con ellos se aparta de los apetitos carnales. El hombre humilde castiga a los perversos que reniegan de Dios, de sus profetas y maestros y de las Escrituras y, por el contrario, enseña a los demás el deber de sumisión. Finalmente, el hombre humilde se revela por la discreción de su apariencia y de su hablar.

Ibn Pakuda trata también de las circunstancias de la humildad y que la virtud de los humildes y la sinceridad de su corazón aparecen en diversas circunstancias. Cuando es injuriado por palabras y actos, el humilde permanece sosegado y evita vengarse aunque pueda, permanece silencioso y acepta las decisiones divinas. $O$, por el contrario, cuando es alabado por sus obras, él permanece humilde y las considera de poco valor, recuerda el mal que ha hecho y reconoce su indignidad. Si es calumniado, permanece sereno, pues el calumniador es quien pierde sus méritos. Si es colmado por los dones de Dios, permanece en su humillación y no se exalta sino que se mantiene en modestia frente a Dios. Por último, podemos decir que soporta todos los sufrimientos en nombre del Señor.

La humildad es fuente de virtudes. Todas las virtudes nacen de ésta que es la principal y que es imposible sin una sumisión perfecta; ésta, a su vez, no se realiza si no hemos aceptado la dependencia absoluta respecto del Señor:

El hombre no se somete a Dios sino cuando asume en él mismo todas las virtudes del estado de servidumbre, humildad y abandono al Creador, y se aparta de los caminos señoriales, la grandeza, la magnificencia, la elevación, el esplendor, la gloria y otros semejantes ${ }^{\text {i4 }}$.

La humildad y el orgullo no pueden coexistir en el corazón del creyente. Sin embargo, hay que distinguir dos clases de orgullo: el que nace de los logros materiales, que destruye toda humildad del corazón, y el que nace de la satisfacción que siente el hombre por sus virtudes, como el sabio y el justo. Este orgullo puede ser censurable cuando se traduce en menosprecio a nuestros semejantes, pero es loable cuando el justo y el sabio, a causa de sus virtudes, son movidos a proteger y enseñar a sus semejantes. Tal orgullo no contradice ni excluye la humildad.

64 Idem, p. 243 
Para quien la tiene en su corazón, la humildad produce frutos que son paz interior y serenidad ante la suerte que le toque. Ante la desdicha y la fortuna adversa, el humilde es paciente y modesto; encuentra favor entre los hombres y se atrae su amor. Por el contrario, el orgulloso siempre es presa de la inquietud a causa de su ambición, no es capaz de soportar las pruebas del Señor a causa de su corazón altivo y su compañía no es grata a los demás.

El hombre humilde busca los sabios y los escucha, su corazón está más cercano a la sabiduría que el del orgulloso. Es diligente en el cumplimiento de su deber de sumisión y se arrepiente de sus pecados. De este modo, el humilde permanece en el justo equilibrio en que el mundo se encuentra.

Pero hay, dice $i b n$ Pakuda, otros frutos más, que no menciona y que debemos esforzarnos por alcanzar, puesto que son mejores que los ya dichos.

\section{SEPTIMO PÓRTICO}

\section{LA PENITENCIA}

Ibn Pakuda dice que la humildad es la raiz y el principio de la penitencia ${ }^{65}$ y la penitencia es el poder de volver sobre nuestros errores y repararlos.

Por penitencia deberemos entender lo siguiente:

La penitencia, o retomo hacia Dios, es el restablecimiento del hombre rebelde y pecador en la sumisión al Señor, y la reparación de todo lo que él había rechazado del culto divino, por ignorancia o por pasión, por ceguera o a causa de influencias perniciosas que lo engañaron y lo hicieron pecar ${ }^{66}$.

Ibn Pakuda nos dice que hay tres clases de penitentes:

1) los que se arrepienten solo en apariencia pero no en su corazón; vuelven a pecar rápidamente y no oponen resistencia a la pasión;

2) los que se arrepienten en su corazón y en sus actos, tratan de luchar contra la pasión, pero no siempre triunfan, $y$ su alma se inclina a la rebeldía;

3) la última clase es la que agrada al Señor: su razón domina la pasión, experimentan una gran contrición frente a sus pecados y buscan constantemente el perdón. 


\section{OCTAVO PÓRTICO}

\section{EL EXAMEN DE CONCIENCIA}

Bajya ibn Pakuda señala que el examen de conciencia es un requisito necesario para la penitencia y una ayuda para nosotros en los dos mundos.

El examen de conciencia consiste para el hombre en hacer con su razón un recuento exacto de los intereses de la religión y de la vida en el mundo, a fin de conocer lo que de sus actos está en favor o en contra de él ${ }^{69}$.

Surge, entonces, la siguiente pregunta: el examen de conciencia debe tener para todos el mismo rigor? La respuesta, también en este caso, se sigue de la capacidad, el conocimiento y la lucidez de cada hombre: Quienes tienen conocimiento y razón suficiente para realizarlo deben hacerlo, sin pensar en postergarlo, pues la responsabilidad aumenta con la lucidez ${ }^{70}$.

Los caminos para recorrer en el examen de conciencia son varios. Ibn Pakuda expone treinta y nos exhorta a aceptarlos y meditar sobre ellos:

1) Todo hombre debe meditar sobre su existencia, sobre su paso de la nada al ser, su dignidad por sobre el resto de las criaturas y, principalmente, sobre el amor y bondad con que el Señor lo favorece.

2) Contemplar la maravilla que es nuestro cuerpo. Pensar que nuestra existencia, nacimiento y desarrollo son posibles solo por la gracia del Señor es un motivo que nos obliga y nos acerca a cumplir las órdenes de Dios.

3) Examinar que el hombre es la única criatura dotada de razón y discernimiento, nos pone en condición de estar infinitamente agradecidos por ello al Señor.

4) Agradecer a Dios por habernos entregado Su ley para conocerlo, para librarnos de la ceguera y para poder conducirnos en este mundo y en el otro.

5) Considerar el mensaje de la Torá y tratar de comprenderlo en toda su profundidad, haciendo el máximo esfuerzo, pues él es fuente de salvación y de vida.

6) Si nos sentimos inclinados a la rebeldía contra el Pacto, considerar que todo en la naturaleza lo cumple: los astros, las aguas y la tierra permanecen en su lugar y posibilitan la subsistencia del hombre. Lo mismo ocurre con su cuerpo: sus órganos permanecen en sus funciones y obedecen sus requerimientos.

Esto debe persuadir al hombre y hacerlo volver a su sumisión ante Dios.

7) El hombre que se reconoce esclavo del Señor y reconoce las huellas de Sus bondades permanece en Él con corazón puro, en su sumisión; se convierte en un elegido y bendito 
de Dios, lo mismo que el pueblo de Israel que, por sus actos de sumisión, está más cerca del Señor que los demás pueblos.

8) El examen debe considerar también el deber de unificar nuestro corazón para el Señor. Esto se realiza al confesar con fe perfecta la unidad de Dios. La unidad del corazón se realiza mediante la búsqueda solo de la gloria de Dios y el desprecio por las alabanzas de los hombres. Pues Dios no depende de nada y nosotros dependemos de él que nos creó y que conoce lo más intimo de nuestro ser.

9) Debemos estar siempre mejor dispuestos ante Dios que ante cualquier otro hombre, pues Dios es nuestro Creador. Debemos estar prestos a cumplir sus órdenes. Ellas se pueden dividir en tres:

a) Los deberes del corazón, para los que es necesario despojarse de toda preocupación mundana y abandonarse solo en Dios.

b) Los deberes del corazón y del cuerpo y que deben unirse en un solo acto como la plegaria. Para esto es necesario que el corazón esté libre de toda preocupación y que el cuerpo esté purificado y que haya unidad entre lo que la lengua dice y lo que el corazón siente, para no caer en la abominación del Señor.

c) Son los deberes del cuerpo en que el corazón no actúa más que por la intención a que da cumplimiento, como el uso de franjas en los vestidos, inscripciones en los dinteles de las casas, observancia del sábado, etc. Para estos deberes corporales es necesario que haya existido primero la intención de realizarlos en el corazón.

10) Debemos meditar sobre cómo hemos llevado nuestra vida, examinar nuestra conciencia y hacer las cuentas que debemos rendir un dia ante Dios. Enmendar el camino si es necesario, antes de que sobrevenga nuestro fin.

11) Al pensar en que Dios ve todos nuestros actos y pensamientos, nuestra confusión debe crecer, aumentar nuestro sometimiento, lo mismo que nuestros deseos de presentamos ante el Señor con nuestros mejores atavíos.

12) Debemos meditar sobre lo pasajero de nuestros cuerpos y sus preocupaciones, lo transitorio de nuestros afanes y vanidades, frente a la virtud y la sabiduría que son tesoros eternos.

13) Debemos preocuparnos de que el esfuerzo con que servimos a Dios sea acorde a nuestro conocimiento y a nuestra ciencia, sin mezquinar nada, pues, cuando llegue el día del juicio, tendremos que rendir cuentas. También debemos apresurarnos por cumplir nuestros deberes religiosos y no postergarlos, pues la asechanza de la muerte es cierta y nuestros dias se pueden acabar sin haberlos cumplido. Es necesario pagar día a dia nuestra deuda con Dios.

14) Es necesario meditar sobre nuestros amores y afectos. Si amamos y somos solícitos con quienes nos favorecen en este mundo, cuánto más debemos serlo para con Él, que solo nos da Su amor y los frutos de Su gracia desinteresadamente y sin que nosotros los merezcamos. Sin embargo, hay quienes se rehúsan a la sumisión y dejan que la pasión se instale en sus corazones y desarrolle su obra destructora. El examen debe llevarnos a despertar de este sueño malvado y abrir los ojos. 
15) Si el hombre prepara con cuidado un viaje largo que debe realizar, cuánto más debe preocuparse de ir bien provisto para el viaje que no tiene regreso.

16) Debemos proseguir el examen con la meditación acerca del tiempo que nos queda sobre la tierra. La proximidad de la muerte que no respeta edad ni condición, debe ser un aliciente, una purificación y una preparación para nuestro corazón enfrentado al juicio de Dios.

17) Debemos preferir la soledad a las muchedumbres y a las reuniones, pues la soledad es un arma que nos protege contra las faltas, pues ellas siempre se cometen en compañia, como las calumnias, las mentiras, etc. Por el contrario, es necesario frecuentar a los Sabios y ser sus adeptos, pues a los hombres que alaban y aman al Señor está reservado el premio.

18) Cuando su alma se hincha de orgullo y de ambición, el hombre debe meditar en la pequeñez de su ser frente a la grandeza del Señor. El ser la criatura dilecta del Señor debe ser causa de mayor sumisión y no de mayor ufanía.

19) Debemos meditar sobre todos los males y desdichas de los que el Señor nos ha librado y, si somos sensatos, nos apresuraremos a adorarlo y a agradecer Sus beneficios.

20) Debemos pensar en lo que poseemos, cómo lo hemos de gastar y pagar. Debemos aceptar que el dinero se pierda o que permanezca en nuestro poder; solo entonces lo usaremos para servir mejor al Señor.

21) Debemos meditar sobre las obras de sumisión que realizamos y esforzarnos por superarlas siempre, hasta que ellas se tornen naturales a nuestros ojos. Debemos mejorar nuestras virtudes siempre aspirando más alto; solo así seremos favorecidos por Dios.

22) Al revisar nuestras relaciones con el prójimo, debemos procurar hacer el bien y aliviar la carga de nuestros hermanos, como quisiéramos que lo hicieran con nosotros. Si no queremos vivir en un mundo desheredado de amor y bondad, debemos preocuparnos por practicar el amor al prójimo.

23) Debemos contemplar al mundo y a sus criaturas, abrir los ojos y ver con una nueva mirada lo ya visto mil veces, asombrarnos con lo cotidiano. En realidad, debemos abrir los ojos del corazón y no cansarnos jamás de alabar a Dios por la grandeza de Su creación manifiesta tanto en lo oculto como en lo evidente.

24) La misma actitud de asombro debemos tener frente al conocimiento de Dios, el estudio de los escritos y la grandeza de Su ciencia. Debemos estar siempre atentos y con ojos de aprendiz, asombrándonos tanto de lo nuevo como de lo ya aprendido, para no caer en la indiferencia de la costumbre y de lo sabido.

25) En lo concerniente al alma y al cuerpo, debemos tender hacia la preferencia del alma y el mundo futuro, pues ellos son los verdaderos. Pero es necesario mantener una justa medida, porque de este mundo serán recogidas las provisiones para el viaje eterno.

26) Cuando cometemos una falta, es menester sumirnos en la más profunda confusión ante Dios. Puesto que Él conoce todos nuestros actos y pensamientos, debemos buscar el perdón con prontitud antes de que el castigo sobrevenga, tanto aquí como en el Más Allá. 
27) Si sobreviene la desdicha, es la voluntad del Señor, pues el dolor y el sufrimiento son medios para alcanzar la beatitud eterna.

28) Si el hombre abandonado sufre los embates de los designios divinos, debe esperar y permanecer en su abandono, pues él ya no se pertenece a sí mismo, sino solo a Dios, y el Señor conoce los caminos de su felicidad, aun cuando no sean evidentes.

29) Al meditar respecto de la superioridad del alma sobre el cuerpo, debemos buscar el bienestar del alma, pues es mucho más dificil mantener la salud del alma que curar la más grave enfermedad del cuerpo.

30) Debemos meditar sobre nuestra condición de extranjeros en este mundo, en el que marchamos solitarios sin que nadie pueda hacemos bien o mal, solo Dios. Entonces, debemos aislarnos en nuestra sumisión y no esperar nada de nadie, excepto del Señor, porque en todas las cosas estamos solos.

Estos treinta métodos tienen por objeto despertar nuestro entendimiento, sustraernos de nuestra ceguera y mostrarnos un camino. Meditar reiteradamente en ellos traerá luz y esperanza a nuestra alma.

La utilidad del examen de conciencia es semejante a la de los ungüentos y aceites que sirven para pulir los objetos. Ellos hacen desaparecer las manchas y las sombras, y entonces las cosas se pueden percibir con claridad. De este modo, el examen de conciencia sirve para iluminar al hombre en la contemplación del mundo espiritual sin la sombra de la duda que enturbia la verdadera mirada sobre el conocimiento de Dios.

El examen de conciencia debe ser practicado en todo momento, pues la mirada de Dios sobre nosotros es constante. La Escritura nos ordena meditar sobre Dios todos los días y en cada momento. Debemos realizar el examen de conciencia con el ritmo de la respiración y contemplar en él hasta lo más nimio, pues la menor virtud realizada es grande ante Dios, lo mismo que la más pequeña falta se torna grave ante Sus ojos.

La relación entre la vida interior del hombre y sus obras depende de la pureza de su alma. El hombre sometido y que cumple con el examen de conciencia vive sin las preocupaciones mundanas, pues su corazón está iluminado con la luz de la verdad. Su vida se torna alegría y regocijo pues el conocimiento de Dios es el único bien necesario.

\section{NOVENOPÓRTICO}

\section{LA ASCÉTICA}

La ascética, nos dice ibn Pakuda, es uno de los modos del examen de conciencia. Ella es beneficiosa a nuestra vida religiosa y profana, da paz a nuestra alma y cuerpo en los dos mundos. 
Según las palabras del autor, debemos entender la ascética general como

El embridamiento de los apetitos por una razón determinada, la privación voluntaria de satisfacciones que se tienen que se tiene la ocasión y la capacidad de saciar. Se ha dicho: 'el asceta es el que puede y renuncia" 73.

La ascética general es privación de lo superfluo, conviene a la salud fisica del hombre, es común a todos y está presente incluso en las leyes civiles que prohíben los excesos.

Existe también una ascética especial. Ésta es una exigencia de la Torá y es un beneficio para la salud de nuestra alma en el otro mundo; contribuye al equilibro de nuestra alma con el orden universal.

La ascética y los ascetas son necesarios a la humanidad. Ellos son uno de los pilares del mundo y nosotros tomamos sus ejemplos, pues no todos estamos en condiciones de vivir ascéticamente, ya que eso perjudicaría el desarrollo de la civilización.

Ibn Pakuda dice que la ascética general es un rechazo del reposo y de los placeres carnales que no son absolutamente necesarios para la vida ${ }^{72}$. Todos los creyentes, aduce, deben someterse a ella pues el objetivo de la Torá es hacer triunfar la razón por sobre la pasión.

Pero en nuestra vida diaria vemos todo lo contrario: vemos que es la pasión la que gobierna nuestra vida; por eso, es necesario que existan hombres en Israel que practiquen una ascética especial para ser ellos útiles a los demás, y se comporten como verdaderos médicos de la fe. Estos hombres especiales tienen por objetivo curar a aquellos que tambalean en la fe, son garantes del perdón divino y llevan la paz y misericordia a las almas afligidas.

Existen diferentes categorías de ascetas. Los verdaderos ascetas se apartan del mal siguiendo el camino trazado por la Torá. Se pueden dividir en tres categorias:

1) El asceta que renuncia a toda la vida material. Queriendo practicar una ascética superior para iguaiarse a los seres espirituales, se aleja de los hombres y huye a los desiertos. Esta clase de ascetas es la más alejada del camino que la Torá traza, pues no es la voluntad de Dios el destruir toda la vida material y social.

2) Los que permanecen en un justo medio desprecian todo lo superfluo pero no se apartan de los hombres. Están más cerca del camino trazado por la Torá, pues viven en la soledad de sus casas, sin huir del mundo.

3) Los que toman el camino más moderado de la ascética. Rechazan lo mundanal en su corazón, pero trabajan en lo material para su subsistencia, siembran y practican el culto religioso. Tienen la certeza de que el hombre tiende a la vida espiritual, pero que se 
encuentra preso en su cuerpo material. Entonces esperan gozosos el día de la muerte como la liberación y comienzo del camino verdadero. Es así como se ocupan de estar preparados para el viaje.

Existen, también, falsos ascetas, seres reprochables y reprobables. Tales son los que quieren ganarse fama de ascetas y llenarse de alabanzas, o quienes por temor a perder sus riquezas, se privan de gastarla y llevan una vida miserable, o quienes son realmente pobres, pero por temor a la vergüenza pública asumen una condición de ascetas para disimular su pobreza.

Para saber si un asceta es verdadero hay que conocer las condiciones de la ascética perfecta. Ellas están presentes en un asceta verdadero, en quien se pueden ver realizadas las mayores virtudes tales como el amor al prójimo, la discreción y el afán de hacer el bien. Pero podriamos resumirlas todas diciendo que el asceta verdadero nutre su vida espiritual de los deberes de los corazones, de los cuales trata esta obra.

El autor insiste en que la ascética exigida por la Torá se debe practicar en tres ámbitos: la vida comunitaria, la personal y la interior:

1) En la vida comunitaria debemos ser amables en todo sentido para con los demás y practicar el bien decir, alejarnos de los lugares de dispersión y orar al Señor solo frente a Él y no frente a los hombres.

2) En la vida personal hay que preocuparse de aquello que nos está prohibido, como los alimentos, las uniones ilícitas y la mezcla de semillas e hilos para nuestra vestimenta. Estas prohibiciones deben llegar a ser naturales en nosotros, es decir, su práctica no nos debe resultar forzada.

En cuanto a los actos permitidos, debemos imponernos en todo momento la mesura, pues el abuso de lo permitido lleva fatalmente a lo prohibido. Pero, por sobre todo lo demás, debemos cuidarnos de nuestros sentidos, en especial de nuestra lengua. Debemos imponemos silencio ante todo aquello que no es necesario, pues, en el poder de la lengua están la muerte y la vida ${ }^{73}$. No debemos permitir que nuestros oídos escuchen discursos superfluos ni mentiras ni maledicencias. En cuanto a nuestras comidas, ellas deben ser lo más frugales posible, pues la abstinencia es el camino correcto para la sumisión.

3) En nuestra vida interior, debemos prestar atención a cuanto se refiere a nuestro pensamiento y nuestro corazón, imponiéndoles disciplina. El primer paso consiste en renunciar con nuestros actos y con el corazón a todo lo que no sea absolutamente necesario para nuestra subsistencia. Debemos lograr que ellos tiendan a acercarnos a Dios y no a alejarnos de lo que Él nos ordena, como el deber de procrear y guardar las fiestas. 
En las Sagradas Escrituras podemos ver numerosos ejemplos de ascética, como el de Moisés, Job y Daniel, entre muchos otros. Todos ellos despreciaron las cosas del mundo en favor de una mejor forma de sumisión y adoración a Dios. A cambio de ello, el Señor nunca los abandonó y les concedió aquello por lo que rogaron.

Sin embargo, debemos saber que hay una considerable distancia, una "caida de las edades" entre la época de nuestros padres y la nuestra. Para Abraham, Itzjak y Yaacov bastaban solo unos mandamientos para cumplir la sumisión y conducirse como ascetas, pues ellos tenian el corazón puro y la razón dominaba sus actos. Con el tiempo y las generaciones, la corrupción aumentó y con ello, el rigor de la Ley y la necesidad de una ascética más severa.

Por todo lo anterior es necesario que abramos nuestros corazones y escuchemos la exhortación que se nos hace, pues cada día será más difícil cumplir con este deber del corazón.

\section{DÉCIMO PÓRTICO}

\section{EL AMOR DE DIOS}

Como ya vimos, el objetivo de la ascética era unificar el corazón del hombre para el amor de Dios. El amor de Dios es el grado máximo al que podemos llegar los hombres y todos los pórticos anteriores no son sino escalones necesarios para llegar a este último. Los deberes de los corazones son los requisitos principales para acceder a este nivel, pero también lo son todas las prescripciones que se pueden encontrar tanto en la razón, como en las Escrituras y la tradición.

El primer paso para acercarnos a Dios es el temor. Primero debemos temerle y luego amarle, pues así está dicho:

Ahora pues. Israel, el Senior tu Dios pide de ti que además de temer al Señor tu Dios,
marches por sus caminos y lo ames, para servir al Señor tu Dios con todo tu corazón y
con toda tu alma (Deuteronomio 10:12)

He ahí la razón por la que, primero, debemos abandonar el amor a este mundo, como fue explicado en el pórtico anterior, para luego poder amar a Dios libres de toda atadura.

El amor a Dios es un impulso del alma que, en su esencia se destaca hacia Dios para unirse a su altísima luz ${ }^{75}$.

74 Idem, p. 344.

75 Idem. p. 345. 
La función del alma es desear todo lo que es bueno y todo lo que ahorra sufrimiento al cuerpo al que Dios la ha ligado para que le sirva de guía.

Cuando, por las contingencias materiales, el alma tropieza en su tarea, la luz de la razón se impone como reveladora de la verdad y de lo superfluo de las ataduras mundanas. Entonces el alma retorna a su camino.

Este camino conduce al abandono de todo deseo y apego a este mundo y a concebir la grandeza de Dios y de su Torá. El alma solo espera en Dios, tanto si goza de sus gracias como si sufre la desdicha. No hay diferencia, pues ya está abandonada y en sumisión perfecta. Puede practicar ya el amor a Dios.

Este amor de Dios tiene diferentes aspectos. Al igual que el amor de un subalterno hacia su superior, puede presentar tres aspectos:

1) puede amarlo porque lo favorece;

2) puede amarlo porque le perdona sus faltas, $y$

3) puede amarlo por su grandeza y elevación, y venerarlo por su sola gloria, sin esperanza y sin temor.

Nuestro amor a Dios puede llegar a tener estos tres aspectos $y$, más aun, es nuestro deber intentarlo porque así está dicho:

Amarás al Señor tu Dios con todo tu corazón, con toda tu alma y con todas tus fuerzas (Deuteronomio V1, 5).

Es decir, amarlo con un amor total, que nos comprometa por entero; por lo mismo, debe ser manifestado al exterior, como el corazón manifiesta su vitalidad.

Para poder caminar por la senda del amor de Dios es necesario cumplir con las condiciones preliminares que son los deberes de los corazones y cumplirlos doblemente, es decir, con perfección. Cuando todas estas condiciones se enraizan en nuestro corazón y se traducen en la práctica de la ascética y en el deseo de conocer y unirse a Dios, entonces brota el amor de Dios, cuyo mayor móvil es el temor, pues al reconocer la grandeza del Señor frente a nuestra pequeñez, se impone nuestra confusión delante de Él.

Cuando el hombre llega a este nivel, no hay más amor que el amor de Dios y no hay más temor que el temor de Dios.

Pero surge la pregunta: ¿puede el hombre amar a Dios? Para responderla, tenemos que establecer primero que el amor reviste tres aspectos: hacer ofrenda de los propios bienes en aras del amor; hacer, además, ofrenda del propio cuerpo, y hacer ofrenda del alma y de la vida. Abraham manifestó su amor de todas estas formas: no tenía apego a su dinero, era hospitalario y generoso; no dudó en entregar su cuerpo y aceptar la circuncisión y, por último, llegó a entregar su alma, es decir, a su único hijo, Isaac. 
El amor de Dios en este alto nivel no lo pueden practicar todos los hombres, solo algunos elegidos del Señor, como sus Santos y Profetas, pues ellos gozan de su ayuda. Al resto de los hombres que ansian llegar a este nivel, se les oponen la naturaleza y el instinto.

Sin embargo, puede alcanzar los dos primeros tipos de amor quien se esfuerce por cumplir las condiciones expuestas en los pórticos precedentes; este es el verdadero camino del temor, el amor y la esperanza. Quien persevere podrá llegar al nivel de los elegidos.

Es necesario tener presentes los obstáculos que debemos sortear para alcanzar el amor de Dios y que son muchos; pero los principales son justificar a los malvados y condenar a los justos.

Los signos del amor, a través de los cuales podemos reconocer a los verdaderos amantes del Señor, son: el temor de Dios reflejado en sus rostros, pero no el temor a Su castigo, sino el temor a Su grandeza, a Su gloria y a la magnitud de Su potencia. El amante del Señor enseña Sus preceptos sin el temor a ser rechazado y sin la esperanza de ser alabado por ello; constantemente alaba al Señor con sus actos y sus palabras; jamás jura el nombre de Dios en vano; es un hombre lleno de alegría, pero permanece en contrición por sus pecados, ora durante la noche y ayuna durante el día en la medida de sus fuerzas. La oración nocturna es la que más agrada al Señor, pues a esa hora el hombre se encuentra libre de preocupaciones y requerimientos. Por último,

el amante del Señor posee la alegria y el júbilo en Dios. En su conocimiento tiene el deseo potente de su voluntad, la alegría de su Torá y ternura para quienes temen al Altísimo ${ }^{76}$.

Para concluir, ibn Pakuda intenta el retrato de los amantes del Señor. Aduce que sus caracteres son numerosos y señala algunos:

- son hombres que conocen a Dios y han comprendido la voluntad del Altísimo;

- se desprenden del mundo y de sus seducciones;

- dan constantemente gracias a Dios;

- se olvidan de sus intereses y de su cuerpo, a no ser en lo estrictamente necesario para su subsistencia;

- están siempre deseosos de servir a Dios con perfecta sumisión;

- en la convivencia con sus semejantes son suaves y discretos, y solo procuran enseñar el verdadero camino a los demás;

- al haber llegado al grado máximo, su faz y su corazón están iluminados con la luz del Señor;

- a ellos, los mandamientos de la Torá les han parecido poco y han buscado el deber que los obligara siempre y en todo lugar: buscaron los deberes de los corazones. 
Estos son los hombres que más se acercan a los Santos y a los Profetas. Ibn Pakuda nos exhorta a seguir sus pasos, etapa tras etapa, si queremos alcanzar el grado más alto y estar más cerca de Dios.

Ibn Pakuda finaliza su obra diciendo:

\begin{abstract}
Medita siempre sobre estas verdades en tu aima y emplea tus fuerzas en apartar los deseos del mundo y en reemplazarlos con aquello que dé acceso a una felicidad eterna, con una concentración constante del pensamiento sobre los deberes del corazón. Así obtendrás la conformidad de Dios y Él dirigirá hacia ti Su presencia de luz para aprobar tus obras y perdonar tus faltas...

Que Dios, bendito sea, nos ensefie con sus misericordias, a mi y a ti, el camino por el cual hemos de ser Sus siervos, Amén ${ }^{77}$.
\end{abstract}

\title{
MI LECTURA
}

Los deberes del corazón es una obra de carácter religioso-moral que apunta a remover la conciencia del hombre creyente. Es una obra eminentemente apelativa y argumentativa en donde, progresivamente, se van estableciendo las pruebas racionales y religiosas por las cuales debemos convencernos de cumplir con los deberes del corazón.

Es una obra que persigue fines traducibles en obras humanas, es decir, está dirigida a un lector real. Ibn Pakuda, en la introducción a su obra, expone las razones por las cuales llegó a concebir una obra como ésta. El principal motivo es la carencia de un tratado sobre los deberes interiores, la ausencia de una guía que iluminara a los hombres en el camino del sometimiento a Dios.

La base sobre la cual ibn Pakuda desarrolla su discurso es la aceptación de la palabra de la Biblia como "la verdad" acerca de la creación, del mundo y del hombre. El supuesto principal es la aceptación de un Dios creador, revelado a través de la palabra (Ley). Sobre la base de la existencia de Dios se construye todo el resto de la obra.

Aceptado que Dios existe, el problema es aclarar el tipo de relación que los hombres establecen con El y las verdaderas características que pueden ser predicadas de Dios, para discernirlas de las falsas.

El inicio de la obra es lo que se cree acerca de Dios, cuyo primer pórtico se llama precisamente, la unidad de Dios. El resto de los pórticos apunta a poner de manifiesto los deberes del corazón, llamados también por el autor, deberes interiores. Estos deberes tienen su fuente en 
la Escritura, la tradición y la razón. Son deberes del corazón que no tienen un ritual establecido, son deberes interiores solo traducibles en el sentimiento religioso que cada uno de ellos comporta.

Ibn Pakuda va paso a paso, de menor a mayor, en la exposición de sus pórticos y sus argumentos, construyendo su obra cada vez más alto. Es decir, parte con los deberes elementales e indispensables para ir más adelante y más arriba. Cada uno de los pórticos se constituye en un escalón necesario para el siguiente, hasta llegar al más alto, al último pórtico, denominado "El amor de Dios".

El enfoque fundamental, a mi juicio, es enfrentar al creyente en su relación con Dios, prescindiendo de lo contingente y de todo elemento circunstancial: lo importante para ibn Pakuda siempre es el corazón del hombre frente a Dios. La relación debe ser univoca y excluyente de otra criatura; es el hombre dirigido hacia Dios a través de sus deberes religiosos, nunca el hombre perdido en sus prácticas y cultos mecánicos, sino el hombre en esencia: su alma, su corazón, libres de las ataduras del cuerpo. Es el hombre enfrentado a su destino fatal, a su suerte última: la muerte del cuerpo y la certeza de una recompensa o castigo a los que se hará acreedor en una vida posterior, de acuerdo con sus obras y sentimientos. Será Dios, concebido como único, omnipotente y omnipresente quien otorgará el premio o el castigo.

Los deberes del corazón es, sin duda, una obra escrita en un lenguaje simple y directo. Conmueve sin perturbar el espiritu, apela al hombre de siempre, a pesar de su explícita direccionalidad y del tiempo que ha transcurrido desde que fue escrita. Transcurridos casi nueve siglos, tiene mucho que decir aún, pues el hombre a quien ibn Pakuda habla es, en esencia, el mismo de entonces y de siempre, con los mismos temores, las mismas esperanzas, con la misma alma.

Ibn Pakuda nos habla sobre nuestra despreocupación de la relación con Dios, de la poca pertinencia que otorgamos a la razón en materias religiosas, del estrecho concepto que manejamos de religión (casi religiosidad), enfrentando el culto al sentimiento, la forma al fondo, to superficial a lo importante.

A pesar de estas dicotomías que llegan a infiltrarse en la obra de ibn Pakuda, ellas no logran establecer oposiciones dentro de su obra pues, dentro de su concepción religiosa, no hay escisiones, no hay conflictos: el conflicto es nuestro.

Mi lectura apunta a destacar que Los deberes del corazón es un discurso vigente, actual y vital que aún hoy a nosotros, hombres gentiles, puede decirnos cosas importantes y útiles para nuestra vida moral, aun si no fuésemos creyentes. 
El midrash halajả se distingue del midrash hagadá no solo por el contenido, sino también por el carácter más circunspecto del primero, ya que la halajá era base de legislación y sus interpretaciones tenían fuerza legal.

El origen del midrash debe buscarse en la insuficiencia de los códigos bíblicos para abarcar todos los aspectos de la vida diaria y para corresponder a los cambios constantes en la vida nacional.

La obra Doctrina de los deberes de los corazones puede calificarse como literatura midráshica, en tanto intento por desentrañar un sentido no suficientemente explícito en las Escrituras, que se traduzca en una nueva interpretación, y en última instancia, en una conducta mejor. Se considera que el principal modelo y método de este tipo de literatura es el de la Biblia.

La vinculación estrecha del pueblo judío con la palabra ha llevado a la proliferación de literatura, a partir de un modelo incuestionable: la Biblia. En ella se encuentran los métodos y los tópicos útiles y verdaderos para el hombre. Este modelo se traduce en normas de conducta, en principios axiológicos que rigen todos los aspectos de la vida de un judio.

Para nuestro enfoque interesa destacar dos premisas básicas del mandato divino al pueblo: estudiar y enseñar.

La enseñanza es quien ha dado como resultado el caudal de literatura exegética que constituye la base de la tradición judaica, mostrada con claridad en el esquema anterior.

El midrash se articula dentro de la corriente de la enseñanza. La Doctrina de los deberes de los corazones se inscribe también en esta línea, en tanto que es un intento por dar una nueva interpretación a las Escrituras.

La obra, entonces, se plantea en una línea de sucesión ininterrumpida, adhiriendo a una forma establecida por la tradición y a un método asumido como correcto y verdadero.

Podemos decir que la interpretación judía, en sus variadas formas, puede reducirse a un esquema básico invariable:

\section{TEXTO+COMENTARIO ${ }^{81}$.}

Aun cuando su estructura es mucho más rica y compleja, también la Doctrina de los deberes de los corazones puede reducirse a este simple esquema. Su estructura última es el texto bíblico más un extenso comentario traducido en la enunciación y estudio de los diez principios (pórticos) que constituyen la obra y que buscan una aplicación real en la vida del hombre.

La presencia tanto de la Escritura como de la tradición sinagogal se da como una estructura, más que como fuente de motivos o temas. La presencia abrumadora de citas biblicas y 
talmúdicas, de los tratados de los doctores y maestros del judaísmo, especialmente de Avot $^{82}$, están dando cuenta de un fenómeno mayor.

Podemos decir que la estructura del discurso de la obra se entreteje en forma y contenido con estas citas, como se aprecia en el siguiente pasaje:

Y si el hombre se apoya sobre la inmensidad de su riqueza, ella le huye y queda solo. Se acuesta rico, muere despojado; abre los ojos y todo ha desaparecido (Job 27:19). Que no se atormente, entonces, para enriquecerse, y no aplique en esto su inteligencia. ¿Proseguirá contemplando lo que va a desaparecer? Pues la fortuna está hecha con alas y, como el águila, levanta su vuelo hacia los cielos (Proverbios 23:4,5). En medio de sus días, el hombre debe abandonar todo, o bien, él no goza más de nada, pues Dios se lo impide (Jeremías 17:11). Su riqueza es para él un depósito que cuida hasta el día en que debe ser entregado a su verdadero destinatario (Eclesiastés 6:2). Dios confia al pecador el cuidado de reunirla y aumentarla, pero para darla a quien es por "Él amado. El perverso acumula, pero el justo se viste (Job 27: 17) ${ }^{83}$.

Es un discurso que se plantea en continuación tan estrecha y natural con el discurso de la tradición que no tiene conflictos en aparecer lleno de citas. Por el contrario, este hecho se constituye como requisito y prueba de autoridad de lo que se dice. El fenómeno que se produce, más que de intertextualidad, puede denominarse de cotextualidad, es decir, un texto al lado del otro; el texto modelo otorga estatus y autoridad al texto continuador.

El método utilizado por el midrash, en este caso, midrash hagadá (filosófico-religioso), privilegia el uso del ejemplo y la comparación, métodos privilegiados también en la tradición.

La construcción de parábolas constituye un nivel de mayor elaboración.

Este método responde a la necesidad de enseñar de manera simple y directa, con un lenguaje claro, el sentido que se intenta mostrar al hombre común. Este objetivo está sefialado por el autor:

Mi único deseo es que se me comprenda. Con el vocabulario de que dispongo, diré lo que estará presente en mi espiritu en lo que concierne a los deberes del corazón ${ }^{84}$

Pirké Avot: Tratado breve de la Mishná, de contenido ético, colocado generalmente al final de Nezikin. Se compone de aforismos y sentencias atribuidas a autoridades rabinicas, desde Simón el Justo, hasta la terminación de la compilación de la Mishná $\mathrm{y}$, por tal motivo, se llama Padres o Sentencias de los Padres (...) Los aforismos, breves y concisos fueron seleccionados para dar una sentencia de la enseñanza caracteristica del maestro (...)

Pirké Avot es uno de los tratados más populares del judaismo, lo que se ve por su inclusión en la liturgia. Se ha convertido en verdadero manual del buen vivir (...). La importancia del tratado es paralela a la del libro de Proverbios en la Biblia. 
Dentro de las citas biblicas y de la atracción de otros tratados hacia el texto, podemos establecer niveles que dan cuenta de un uso progresivo de la creación personal y un desapego de lo textual.

El sentido general de la obra emana de la necesidad de un tratado sobre los deberes del corazón, debido a su ausencia expresa en la tradición, aun cuando se percibe su presencia -en forma más o menos velada-, en las Escrituras. La explicitación de tales deberes da como resultado una obra nueva en cuanto al tema, pero necesariamente tradicional en cuanto a la forma. Como ya hemos dicho: texto más comentario.

Sin embargo, al asumir y hacer propia tanto la tradición como el discurso ajeno, se puede notar una fuerza centrífuga que opera en sentido contrario, y que da como resultado la belleza de la obra. Esta fuerza centrífuga que opera en el texto se da en forma diferenciada y se pueden distinguir grados o niveles.

Un primer nivel es aquel en que el discurso ajeno aparece claramente señalado como tal. Este es el caso de mayor frecuencia:

Los justos y los que se abandonan a Él se confian en el Señor y lo exaltan los corazones reçtos (Salmos 64: 11).'Luz y felicidad irradian de ellos' canta David (Salmos 97:11)" ${ }^{\prime 25}$.

Un segundo nivel es aquél en que lo dicho, y que pertenece en rigor a un discurso ajeno, aparece solo marcado por una alusión:

Un sabio ha dicho: Me sorprendo que aquel que pasa dos veces por el canal de la orina y de la sangre, pueda enorgullecerse e hinchar su corazón ${ }^{86}$.

Un tercer nivel consiste en la ausencia total de texto, es decir, aparece el rótulo de un ejemplo, una historia o una fábula conocida, y con esto se apela a la competencia del lector en el conocimiento de la tradición:

... Pero quien espera que Dios se lo ofrezca sin el conducto de los actos es un simple o un tonto, es Zimri, exigiendo el salario de Pinjas ${ }^{87}$.

Estos tres niveles que hemos señalado están, en conjunto, apuntando a la concepción de lector que se maneja en el texto y a su grado de participación en la construcción del sentido de la obra. Es importante tener en cuenta que siendo una obra de un autor judío y con un contenido judío, el lector supuesto será, necesariamente también, un lector judío, quien tendrá la competencia necesaria para actualizar los textos atraídos por la escritura y llenar los vacios de los rótulos que hemos señalado. 
Este es un texto que completa su realización por la capacidad del lector, tanto para actualizar los elementos que aparecen aludidos, como para llenar lo que el autor está tratando de decir:

Hemos establecido suficientemente el deber de contemplar las criaturas y de sacar de ello las pruebas de la divina sabiduría.

$\mathrm{Y}$ tú, por ti mismo, has de comprenderlo ${ }^{\mathrm{*}}$.

Por último, dentro del despliegue de estos niveles, la construcción de parábolas para entregar el mensaje, se instala dentro de la fuerza que hemos llamado centrifuga (solo en el sentido de que se presentan en apariencia de creación personal), es decir, que ellas son lo que podríamos llamar el verdadero discurso (poético) de nuestro autor.

Por otro lado, son también el método por excelencia de la literatura midráshica, y sin duda una de las más bellas formas de enseñar ${ }^{89}$.

También es posible pensar y decir que, en la construcción de estas parábolas, se incorporan elementos de la tradición oral tanto judía como genti $1^{90}$. Estamos pensando principalmente en la literatura sufi, vigente en la época de producción de la obra (recordemos la presencia árabe en España), y presente en su tratamiento temático, particularmente en la idea de la superioridad de la vida espiritual por sobre la material.

Para mostrar un ejemplo de esta influencia vamos a mostrar una parábola de nuestra obra $y$ un texto de literatura suff:

\section{LAPARÁBOLADELESPEJO}

Imagina que estás en un lugar, encima del cual, detrás tuyo, se cierne una forma sin que se logre percibirla y considerarla. Siguiendo un consejo, tomas una placa de acero, la pules hasta quitarle su opacidad y la untas largamente con numerosos aceites. La pones luego ante tu mirada y descubres entonces, la forma elevada que se te escapaba. Puedes contemplarla y deleitarte con su deslumbrante y magnifica belleza. La elevada forma que nos es imposible contemplar con la mirada es la ciencia suprema, el poder del Altísimo; es el esplendor del mundo espiritual que escapa a nuestros sentidos. La placa de acero es el alma humana; el pulimento es el ejercicio en la sabiduria y en las disciplinas racionales y reveladas. Finalmente, la untura es el examen de conciencia cuyos treinta métodos hemos determinado ${ }^{91}$.

89 Al final del trabajo se presenta un corpus de parábolas. Ellas son un compendio de momentos en que el autor ejemplifica de esta forma.

90 Por tradición, el término 'gentil' se entiende, desde el punto de vista judío, como no judio. Esto se relaciona con la concepción judia respecto a la diferencia entre "goy kadosh" (puebio santo, como se menciona a lsrael en la Biblia) y el resto de los pueblos (goyim).

91

Haleh, Bakhtiar, Sufi. 


\section{EL.TEXTO SUFÍ}

Dios es la luz de los cielos y de la tierra. Esta luz es como in foco en el que hay una llama, una llama colocada en un cristal, cristal semejante a una estrella brillante; esa llama se enciende con el aceite de un árbol bendito de un olivo que no es de Oriente ni de Occidente, el cual aceite brilla aunque el fuego no le toque. Es luz sobre luz. Dios conduce hacia esa luz al que quiere y propone a los hombres parábolas, pues lo conoce todo ${ }^{92}$.

Al cotejar ambos textos, podemos ver el uso de elementos comunes que apuntan a señalar un mismo sentido, el de una forma superior de conocimiento de la luz divina. A través de la gracia divina, en el caso del texto sufi, y a través del esfuerzo personal, en el caso de nuestra parábola, nos están mostrando que el área de contacto y de vigencia de la literatura sufí toca directamente a nuestro autor.

Podemos notar también que el uso de estos elementos pasa por una elaboración que hace que el producto resultante sea diferente. La originalidad consiste en tomar lo dado, -quizás en forma eclectica-, y transformarlo para poder aplicarlo a las necesidades particulares de la obra.

Como quiera que se presenten estas parábolas en el texto, constituyen el elemento más bello de la obra, el midrash.

\section{B) LA OBRA COMO DISCURSO RETÓRICO}

Como hemos dicho, la Doctrina de los deberes de los corazones es una obra cuyo objetivo manifiesto es convencer al judio que la leyera para cambiar de manera radical su actitud espiritual y moral para con Dios. En este sentido, es claramente un discurso de persuasión y debe necesariamente ubicarse dentro del manejo retórico del lenguaje.

Se nos presenta así la tarea de determinar de qué forma se realiza esto y de qué manera se articula esta realización particular con la retórica clásica y las posibles variables que presenta.

Iniciamos este enfoque, afirmando que la Doctrina de los deberes de los corazones se inscribe como discurso en el ámbito del discurso de la religión. Éste tiene como característica esencial ofrecerse como discurso verdadero, en tanto que está apoyado en la palabra de Dios. Esto es especialmente válido para un discurso hecho por un autor judio que lleva consigo la tradición bíblica de un Dios que creó el universo con su palabra ${ }^{93}$.

Estamos hablando entonces de una concepción lingüistica trascendente, que otorga a la palabra de Dios el poder creador y a su doctrina revelada, el valor de verdad. 
Por otro lado, la obra fue escrita en la España medieval, durante la dominación árabe. Esto conlleva la presencia de un ambiente cultural favorable para la creación de una obra como la Doctrina de los deberes de los corazones.

A la fecha del nacimiento de nuestro autor, la conquista de España por los musulmanes estaba consumada y en la región se vivía un ambiente de paz y prosperidad material y cultural que favorecía la actividad intelectual y permitía libertad y trenquilidad a los grupos domina$\operatorname{dos}^{94}$. Por otra parte, hay que recordar que las escuelas de traductores árabes-judios-cristianos fueron el puente gracias al cual Europa conoció la antigüedad clásica.

Es claro que la educación y los conocimientos adquiridos por nuestro autor comprendieron, además de lo específicamente hebraico ${ }^{95}$, también a los más importantes autores clásicos, sobre todo en materia filosófica. Aristóteles era, en la época, el autor más conocido en la Europa medieval y el que con más claridad aparece en nuestra obra, a través de menciones textuales:

Cuando nos elevamos en la escala de los seres vemos a los géneros tornarse progresivamente menos numerosos hasta los géneros llamados comúnmente categorias, que son según el Filósofo en número de diez: sustancia, calidad, cantidad, relación, lugar, tiempo, posición, tener, actuar, padecer ${ }^{96}$.

Para el interés de nuestro estudio, las concepciones retóricas que se despliegan en la obra y que con mayor claridad corresponden a las nociones de la Retórica de Aristóteles, son las que pondremos de manifiesto.

Comencemos por decir que Bajya ibn Pakuda tiene clara conciencia de que, para cumplir su objeto y llevar a cabo su obra, deberá desplegar estrategias discursivas que caen en el ámbito de la retórica.

Me he abstenido de toda demostración dialéctica y de investigaciones profundas que dificilmente habrian tenido adecuado desarrollo según sus reglas en este libro en el cual sólo he aceptado las pruebas retóricas que satisfacen mi espiritu con el método habitual de la teología ${ }^{97}$.

Lo más acertado es, pues, suponer que lo que ibn Pakuda tiene en mente al enunciamos el plan de obra, son las nociones aristotélicas. Esto se puede demostrar al cotejar las siguientes citas, la primera de Aristóteles y la segunda, de nuestro autor.

Acerca de los fines de éstas y cómo se relacionan entre si, ya queda dicho casi lo suficiente. De la persuasión mediante demostración o demostración aparente, lo mismo

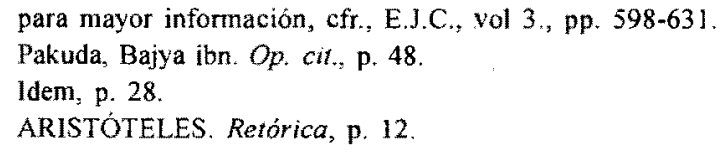


que en la dialéctica hay la inducción, o el silogismo, o el silogismo aparente, también aquí es de modo semejante: pues el ejemplo es una inducción, el entimema es un silogismo (el entimema aparente, un silogismo aparente). Llamo entimema al silogismo oratorio y ejemplo a la inducción oratoria. Pues todos dan las pruebas para demostrar o diciendo ejemplos o entimemas, y fuera de esta, nada; de manera que en absoluto es preciso que cualquier cosa se pruebe o haciendo silogismos o inducción (...) y es forzoso que los entimemas y los ejemplos sean lo mismo respectivamente que los silogismos y la inducción ${ }^{98}$.

Como dice el Filósofo: No conviene dar una demostración apodíctica de todo concepto, pues a veces esta demostración es imposible ${ }^{9 \%}$.

Podemos decir, entonces, que este pasaje se refiere exactamente al texto de la Retórica que aquí hemos mostrado y con esto, dar por probado el hecho de que, en efecto, ibn Pakuda está trabajando de acuerdo con nociones y conceptos aristotélicos.

En este contexto, lo que a nosotros nos interesa dice relación con el modo particular en que las nociones elementales de la retórica clásica se realizan en el texto.

De las cinco partes en que se divide la ciencia de la retórica ${ }^{100}$, a saber, inventio, dispositio, elocutio, actio y memoria, las dos primeras serán las más importantes dentro de la obra. Ello, por tratarse de un discurso que se despliega en la escritura y no en la oralidad. Esto marca su primera y fundamental diferencia con las nociones de la retórica clásica, es decir, que las circunstancias de lo que podríamos llamar la representación del discurso, quedan obviadas por la escritura.

\section{LA INVENTIO}

La inventio, entendida como todo el trabajo de acopio del material a usar y de lo que se va a decir, tiene su diáfana expresión en la introducción que hace ibn Paluda a muestra obra.

Podemos afirmar que es allí donde se vierte el plan de la obra, es decir, se presenta el cómo el autor llegó a la decisión de escribir la obra, las dificultades que encontró, el plan que trazó y los objetivos perseguidos.

El acopio de lo que se despliega en el discurso es el resultado de un análisis de conciencia, de la puesta en práctica, por parte del autor, de sus conclusiones.

Cuando hube comprendido toda la importancia racional, escrituraria y tradicional de los deberes de los corazones, comencé a forjar en ellos mi alma. Me impuse la tarea de

100 PAKUDA, Bajya ibn. Op. cit, pp. 25, 26. 
El dominio de la penitencia es importante y solo el hombre que reconoce el error de su pecado puede practicarla. Aquél que reconoce que habrá un juicio que sancionará sus actos, sabe que el castigo está inevitablemente unido al pecado. Sin este conocimiento, la penitencia no sería posible ni tendría sentido. Debe estar también convencido de que solo la penitencia reparará sus faltas y que ninguno de sus actos se oculta a Dios.

Ibn Pakuda enseña que los términos de la penitencia son cuatro:

1) tener contrición de los pecados;

2) abandonarlos y apartarse de ellos;

3) confesarlos y buscar el perdón, $y$

4) empeñarse con el alma y la conciencia para no reincidir.

La contrición del pecador es el signo de que el pecado le parece censurable. Al abandonarlo, muestra fe en la retribución divina; al confesarlo, hace evidente la verdad de su contrición y, por últímo, la voluntad de no reincidir lo libera del castigo.

Las condiciones de la penitencia, nos dice el autor, nacen principalmente de la contrición sincera y del temor al castigo celestial. Tal contrición se manifiesta en gestos evidentes como las lágrimas, las vestimentas, las palabras y los alimentos.

El abandono del pecado consiste en huir de todo lo que está prohibido. Esto debe ser practicado con fervor y constancia, sin permitirse ninguna ocasión para pecar. Nuestros pecados nos deben parecer muy numerosos y muy graves, y deben estar siempre presentes ante nuestros ojos.

Por otra parte, la oración, la decisión de no reincidir y la meditación acerca de la certidumbre de la muerte harán más fácil el camino del penitente.

Ibn Pakuda propone la exhortación a la penitencia, que puede venir por cuatro caminos diferentes:

1) La exhortación puede venir de la fuerza con la que el hombre conoce a su Dios y contempla su gracia: le es preciso someterse y obedecer a una santa voluntad, inclinarse ante sus justas prohibiciones ${ }^{67}$.

2) Puede venir de la amonestación de Dios a sus faltas a travěs de sus profetas, de la Torá o por la voz de los maestros. La amonestación hace que el pecador vuelva sobre sus pasos y espere el perdón y la gracia de Dios.

3) Puede venir del ejemplo tomado de otro pecador que ha sido castigado. El pecador entonces vuelve a Dios por temor a un castigo más terrible.

4) Puede venir también del remecimiento que provoca en el pecador el castigo que recibe, lo que lo hace despertar del estado de adormecimiento en el que estaba. 
El primero de estos cuatro modos es el más elevado y el que más agrada a Dios.

Debemos tener presente que existen causas corruptoras de la penitencia. Ellas son numerosas y se mencionan varias. La principal es la obstinación en el pecado que hace imposible toda penitencia. La obstinación conlleva a que el hombre orgulloso desprecie la palabra de Dios. Entonces, más vale arrepentirse pronto de un grave pecado que permanecer en uno pequeño, pues Dios todo lo ve. Tampoco vale ante los ojos del Señor el hombre que peca premeditadamente pensando en hacer penitencia después, pues para eso no habrá un después.

El justo y el penitente son pues dos sujetos importantes; algo debe decirse de ellos.

El justo es quien no ha pecado nunca; el penitente es aquél que ha pecado, pero que se arrepiente. A través de la penitencia vuelve a estar a los ojos de Dios al mismo nivel que el justo. El justo es superior al penitente que ha caído en pecado mortal, pues a éste solo el sufrimiento y la muerte lo redimen. Pero el penitente que ha incurrido en pecados menores y se arrepiente es superior a cualquier justo, pues él conoce la humildad y el justo no. El justo por su justicia está en peligro de caer en el orgullo y la hipocresía.

Ibn Pakuda se interroga: ¿es posible la penitencia para todo pecado? Para responder a esta pregunta es necesario señalar que existen dos clases de pecados:

1) La primera comprende los pecados entre el hombre y Dios. Son una rebelión que no implica perjuicios más que para sí mismo, como la negación de Dios, la trasgresión de los deberes del corazón, etc.

2) La segunda compromete a los demás. Abarca las injurias y los daños al prójimo.

Para la primera clase es posible la penitencia en esta vida y la penitencia será acorde al pecado.

La penitencia para la segunda clase de pecados es mucho más difícil, pues el ofendido puede haber muerto, encontrarse lejos o ser el pecado irreparable como el asesinato, por ejemplo, o la concepción de un hijo bastardo, cuya falta es irreparable y cuya evidencia es permanente. Pero la más difícil de todas es la penitencia de aquel que inclina a los demás a la herejía, asi como aquél que puede evitar un mal y por temor o por interés no lo hace.

Existen, nos dice ibn Pakuda, medios para la difícil penitencia:

Cuando la reparación de un daño es dificil por alguna de las razones que hemos dado en el capítulo precedente, el pecador deberá plegarse a todas las exigencias de la penitencia, con todas sus fuerzas, con toda su potencia y Dios le facilitará las cosas, pasará por alto aquello que él ignora, encontrará una salida a su tormento y escuchará sus excusas ${ }^{68}$.

La penitencia no será rehusada a ningún hombre que quiera acercarse a Dios y ningún obstáculo se levantará delante de êl. 
conocerlos y de vivirlos. Cada descubrimiento traía consigo otro. El tema se tornaba demasiado vasto y se volvía una carga pesada para mi memoria. Temía olvidar lo que concebia; temía que huyese aquello que había tomado forma en mi espíritu. Y en esto me encontraba solo, pues mi pensamiento encontraba pocos ecos en mis contemporáneos. Entonces decidi redactar una obra consagrada a los principios, a los detalles y a las consecuencias del asunto que me preocupaba, con la intención de obligar a mi alma a meditar constantemente para penetrarlo e imponerme una disciplina estricta en lo que se refería a su cumplimiento ${ }^{101}$.

Es un esfuerzo personal por indagar la necesidad de su asunto en las fuentes de que dispone. En esta medida, personales serán también las concepciones de los elementos fundamentales de la situación retórica que se manejan, como son los factores del orador, el oyente, el asunto o materia.

En la retórica clásica, el elemento preponderante era el orador. La capacidad del sujeto para convencer, tanto por su capacidad y artifícios como por su calidad moral, hacía de la retórica una ciencia o arte susceptible de ser aprendida.

El asunto en cuanto tal no tenía una importancia especial o determinada de antemano. Podia ser de cualquier índole. Se puede decir, en rigor, que solo condicionaba la forma en que se disponían los argumentos. Era un elemento disponible para que el talento del orador le diese forma.

El oyente, por último, era considerado como grupo, nunca como individuo. Una masa cuyas pasiones podian ser movidas en bloque, por el talento del orador.

Dentro de este esquema, queda manifiesto en la doctrina clásica, el protagonismo del orador por sobre los otros dos elementos.

Vemos de qué modo la jerarquización de estos tres elementos responde a una concepción diferente en la Doctrina de los deberes de los corazones.

El factor más pasivo de la concepción clásica es en nuestra obra el elemento más activo y el más importante. El asunto a tratar, la religión interior ${ }^{102}$, es tan importante que se impone a los hombres casi sin necesidad de un discurso que lo sustente aparte del de las Escrituras:

La ciencia de la Torá comprende dos partes. La primera tiende al conocimiento de los deberes prácticos y es la ciencia de la conducta exterior. La segunda se ocupa de los deberes del corazón, de sus sentimientos y pensamientos y es la ciencia de la vida interior ${ }^{10}$.

Los argumentos que sustentan el discurso de Los deberes de los corazones son, como ya hemos señalado, de tres órdenes: 
Cuando hube comprendido toda la importancia racional, escrituraria y tradicional de los deberes de los corazones, comencé a forjar en ellos mi alma ${ }^{104}$,

Podemos establecer entonces un paralelo de cada grupo de pruebas que se corresponda con cada tipo de fuente. Las pruebas lógicas serán tomadas de las especulaciones racionales; los ejemplos y las parábolas, de la tradición y las pruebas apodícticas, de la Escritura. Es decir, estamos hablando de las pruebas técnicas, aquellas construidas por el orador y de aquellas con valor de verdad por sí mismas.

El uso de pruebas apodícticas será el de mayor frecuencia. Esto se debe a lo que hemos ya señalado respecto del carácter del discurso de la religión, discurso que se plantea como verdadero por sí mismo.

En la obra, el oyente aparece constantemente interpelado en su capacidad individual para comprender y sentir lo que se está diciendo:

Y tú, para ti mismo, has de saber interpretarlo ${ }^{105}$.

$Y$ tú por ti mismo, has de comprenderlo ${ }^{106}$.

Sabe, oh lector, que esta obra sólo ofrece una ínfima parte de un inmenso... ${ }^{107}$

En efecto, la promesa y la amenaza deben hacerse según convengan al tiempo y al lugar. ¿Y tú has de comprenderlo! ${ }^{108}$

El oyente, entonces, está concebido como individuo, a diferencia de la concepción clásica que concebía al público como un todo compacto, una masa homogénea que podía ser convencida o movida al pathos por el ethos del orador. El oyente de nuestra obra es el hombre individuo, apelado en la intimidad de su corazón con sus limitaciones y capacidades.

Ya no es el talento del orador quien obra el cambio, sino, en primer lugar, la evidencia del asunto $y$, en segundo lugar, la capacidad de cada hombre para comprender.

El orador queda reducido en esta concepción a un papel instrumental. La gracia divina lo hizo despertar en un grado superior de conocimiento de Dios y su deber como judío es enseñar a sus hermanos la forma de acceder a ello:

Así consideraba los deberes del corazón y la obligación en que nos encontramos de consagramos a ellos. Vi el abandono en que se encontraban; no habia un solo libro que se les hubiese consagrado. Comprendi cómo el espiritu de nuestros contemporáneos estaba lejos de penetrarlos, y con mayor razón, de practicarlos, de vivirlos. Dios me hizo la gracia de despertarme al estudio de la ciencia interior ${ }^{109}$.

\footnotetext{
104 Idem, p. 25.

105 Idem, p. 47

106 Idem, p. 81

107 Idem, p. 101

108 Jdem, p. 186

109 Idem, p. 24
} 
A los otros hacia falta, de modo apremiante, despertarlos e instruirlos ${ }^{110}$.

Es en definitiva la gracia de Dios quien otorga el don de enseñar y el de comprender. Los hombres por sí mismos solo tienen la facultad de aceptar o rechazar esa gracia.

Hemos visto cómo el tratamiento de los tres factores, el oyente, el asunto y el orador, han sido modificados respecto de las concepciones clásicas y cómo, desplazado al orador de su protagonismo tradicional, se puso en su lugar, como elemento principal de convicción, al asunto mismo (la palabra de Dios).

En la medida en que esto es así, resulta que el sujeto de la enunciación, que en este caso se corresponde con la figura del orador, ha debido construirse una trama de acreditación, un discurso autorreferente que sustente y absorba las posibles fallas que aparezcan en la realización de una tarea de tanta envergadura. Respondiendo a este hecho, podemos encontrar en el texto, afirmaciones como éstas:

Mas, tratándose de realizar el designio en que habia pensado, comprobé que un hombre como yo no era apto para llevar a cabo semejante obra. Medí mi alma y verifiqué que la empresa era demasiado amplia para mi débil inteligencia"l.

Júzgame con indulgencia por los defectos de mi obra, por mis errores, por las debilidades de mi pensamiento o de mi estilo. Me he apresurado a escribirlo, temiendo que la muerte me apremie y me impida realizar mi propósito. Y bien tú sabes que el hombre es demasiado débil por sí mismo para llegar a la plenitud de sus descos ${ }^{112}$.

Sin embargo, las falencias tanto del orador como del oyente quedan soslayadas por el asunto. Él es de indole tan importante y verdadera, presente en la fuente más incuestionable para el hombre judío, que todo lo demás viene a ser mero aditamento: el protagonismo de la palabra de Dios no ceja; por el contrario, sigue estando presente y dando forma a los discursos que la reproducen.

LA DISPOSITYO

La dispositio es la otra parte de la retórica clásica que se realiza de manera significativa en el discurso de nuestra obra.

Hemos señalado que la introducción a su obra es el lugar en donde el autor vierte el plan general. Alli se presentan la obra, sus objetivos y los métodos para realizarla. 
En la introducción se vierte el plan general y con ello podemos afirmar que existe una clara conciencia de que la materia que se va a exponer debe presentar una forma y un plan. Dicho plan presenta la marca de la progresión, es decir, cada una de las partes está tratada según un orden sucesivo, y va ocupando un nivel de sentido cada vez superior:

Hermano, sabe y comprende que los deberes del corazón, las virtudes y dones espirituales que hemos mencionado en los pórticos precedentes son los escalones y los grados de esta realidad suprema por los que penetramos a este último pórtico ${ }^{173}$.

Cada pórtico a su vez se constituye, como una categoria, como un principio contenedor de los deberes que pertenecen a cada categoría:

Cuando hube tomado mi decisión, di forma a la redacción de la obra y preparé sus bases y su plan general. Los compuse con diez principios que abarcan todos los deberes de los corazones ${ }^{114}$.

El ordenamiento de la obra responde, pues, a un plan general que podemos esquematizar de la siguiente forma:

\section{PÓRTICO}

(a) Título de pórtico

(b) Presentación del deber

(c) Título de cada capitulo

(d) Definición

(e) Obligación o necesidad de cumplir con el deber

(f) Modo de acceder a dicho cumplimiento

(g) Diferentes clases del deber

(h) Extensión del cumplimiento

(i) Ejemplos y comparaciones

(i) Elementos de desviación del deber

(k) Formas para evitar la desviación

(l) Métodos y prescripciones prácticas para el cumplimiento

(m) Utilidad y beneficios del cumplimiento.

114 Idem. p. 28. 
Este esquema se realiza, con algunas variaciones, en cada pórtico. Veamos la frecuencia con que ocurre en'ellos cada uno de los elementos señalados:

\section{PÓRTICOS}

\begin{tabular}{|c|c|c|c|c|c|c|c|c|c|}
\hline I & II & III & IV & V & V & VII & VIII & IX & $X$ \\
\hline $\mathrm{a}$ & $a$ & $\mathrm{xa}$ & $\mathrm{a}$ & a & a & a & a & $a$ & $\mathrm{a}$ \\
\hline b & $b$ & b & b & b & $b$ & $b$ & $b$ & $b$ & $b$ \\
\hline c & $\mathrm{c}$ & $\mathrm{c}$ & $\mathrm{c}$ & c & c & $\mathrm{c}$ & $\mathrm{c}$ & $\mathrm{c}$ & c \\
\hline d & $\mathrm{d}$ & $\mathrm{d}$ & d & d & d & $\mathrm{d}$ & d & d & $d$ \\
\hline $\mathrm{e}$ & e & $\mathrm{e}$ & $\mathrm{e}$ & $\mathrm{e}$ & e & $\mathrm{e}$ & e & $\mathrm{e}$ & $\mathrm{e}$ \\
\hline$f$ & $\mathrm{f}$ & $\mathrm{f}$ & f & $f$ & $f$ & $f$ & f & $f$ & $\mathrm{f}$ \\
\hline & $h$ & $\mathrm{~g}$ & $\mathrm{~g}$ & h & $\mathrm{g}$ & $\mathrm{g}$ & 1 & $\mathrm{~h}$ & $\mathrm{~g}$ \\
\hline & $\mathrm{g}$ & $\mathrm{h}$ & $\mathrm{h}$ & $\mathrm{j}$ & $h$ & $h$ & $\mathrm{~m}$ & $\mathrm{~m}$ & $\mathrm{~h}$ \\
\hline & & $\mathrm{i}$ & $j$ & $\mathrm{k}$ & 1 & $\mathrm{j}$ & & $\mathrm{g}$ & $\overline{\mathrm{j}}$ \\
\hline & & $\mathrm{m}$ & $\mathrm{m}$ & $\mathrm{m}$ & & $\mathrm{m}$ & 1 & & $\mathrm{~m}$ \\
\hline
\end{tabular}

Se observa que siempre están presentes $a, b, c, d, e$ y f. El resto varia según la índole de cada uno de los pórticos. Por ejemplo, es imposible que en el primer pórtico cuyo título es "La unidad de Dios", aparezca el elemento j (desviación del deber). Debe quedar entonces claro que la índole del asunto condiciona la forma en que éste se presenta.

Inventio y dispositio, como hemos esbozado en el panorama anterior, son las partes de la retórica clásica que Bajya ibn Pakuda despliega en su obra y que son susceptibles de rastrear con certeza.

Para cualquier acercamiento al texto, deberemos tener presentes como elementos principales los motivos y la concepción religiosa desde la cual está hablando el autor. Y no olvidar que se trata de una obra compuesta para ser leída y puesta en práctica por judíos, que fue escrita para convencer al judio de su época de la importancia del asunto. Para ellos, el sujeto tomará sus argumentos y formas, tanto de la tradición judía como de la tradición gentil.

\section{CORPUS DE PARÁBOLAS}

El corpus de parábolas que cierra este trabajo responde al objetivo de presentar muestras textuales donde se realizan las dos vertientes más pertinentes para acceder al estudio de la 
Doctrina de los deberes de los Corazones. Sean entonces leídas estas parábolas como excelente construcción de pruebas técnicas en el ámbito de la retórica y como muy logrados ejemplos de midrashim judios.

Un rey ordena a uno de sus servidores recolectar de sus súbditos los impuestos. Debe vigilar, pesar y depositar en el tesoro las piezas de moneda. El servidor es muy experto en esta materia, pero los súbditos conspiran tan bien, que logran seducirlo con sus palabras y muy pronto llega a creer en la buena fe de todos. Ellos le llevan su plata y le aseguran que el número, el peso y el valor son exactos. El servidor les cree ciegamente y, por pereza, a despecho de la orden real, descuida verificar sus dichos. Cuando el rey llega a saberlo, pide que se le traiga el tesoro e interroga: ¿Cuál es su peso? ¿Cuál es su valor?, pero el servidor no sabe qué contestar y es castigado, entonces, por haber violado la orden del rey y haber tenido una fe ciega en dichos que, aunque fuesen exactos, pudo haber verificado. Solo si hubiera sido inexperto en esas materias, le hubiera permitido confiar en las afirmaciones de los súbditos.

De la misma manera, si fuera imposible comprender racionalmente cuestiones como, digamos, la de la significación de las leyes reveladas y no fundasen su razón, evidentemente seria excusable el no examinarlas. O bien, en el caso de que tu inteligencia fuese pequeña y tu comprensión demasiado débil para penetrar semejante asunto, no serias castigado por tu abstención: serias como las mujeres y los niños, a quienes basta seguir la tradición. Pero si gracias a tu saber y tu inteligencia, puedes verificar las tradiciones que los sabios recibieron en nombre de los profetas, acerca de los principios de la religión y los pivotes de las obras, debes consagrarte a este examen hasta dominar el asunto y conseguir la verdad de la fe por el concurso de la tradición y de la razón reunidas. Si ignoras este deber y, más aun, si deliberadamente te abstienes de cumplirlo, incurres en falta para con tu Creador ${ }^{115}$.

A fin de experimentar sus cualidades, un rey ofreció un día a sus servidores capullos de gusanos de seda. El más inteligente y el mejor de entre ellos escogió minuciosamente sus capullos y eligió los más bellos e hizo un grupo. De lo que quedaba aún, eligió los más bellos, asi tuvo tres clases de capullos: unos muy bellos, otros medianos y los últimos, comunes. Sólo llevó los muy bellos al más diestro de los artesanos que hizo con ellos espléndidas

115 Idem, p. 22 
vestiduras de colores delicados y variados; luego se cubrió con estas vestiduras para acercarse al rey, teniendo en cuenta el tiempo y los lugares. El servidor insensato hizo con todos los capullos que había recibido lo que el sabio había hecho con los menos buenos: los vendió y se apresuró a gastar su dinero en banquetes y orgías. Cuando el rey se enteró de estas cosas, aprobó el gesto del servidor sabio, lo acercó a sí y lo elevó al rango de los elegidos. La acción del insensato le pareció censurable: lo alejó y lo desterró al más desolado de sus países, entre quienes sufrían las quemaduras de su cólera.

Dios da asi su Torá de verdad a sus servidores para probarlos. El hombre inteligente y lúcido la lee y la comprende claramente. La divide en tres partes. La primera es la que hace conocer las realidades espirituales más sutiles que dependen de la ciencia interior de los deberes del corazón y de las disciplinas del alma. Se obliga a cumplinlos con severidad constante. La segunda está formada por los deberes de los miembros que deben cumplirlos a tiempo y lugares determinados. La tercera comprende los datos históricos de las Sagradas Escrituras, que sirven para conocer los grupos y su historia y el pensamiento y los enigmas de los tiempos pasados. Estudia estas cosas como es conveniente y necesario $y$ siempre aúdate con las ciencias exactas y la lógica, en las que se encuentran las premisas de toda teología. Quien ignora estas ciencias, en verdadignora los signos de la Sabiduria del Creador en sus obras ${ }^{116}$.

$N^{\circ} 3$

Un hombre generoso encuentra en un desierto a un niño lactante; tiene compasión de él, lo adopta lo cría, lo nutre, lo viste, lo provee de todo lo necesario hasta que está en condiciones de comprender la magnitud de su felicidad. Luego, ese mismo hombre llega saber que un cautivo se encuentra en las manos de sus enemigos, reducido al último grado de la miseria, desnudo y hambriento desde larga data. Sus entrañas se conmueven ante tal sufrimiento y, tanto apacigua a su adversario, que éste libera a su víctima. El hombre paga el rescate, adopta al miserable y le dispensa una parte de los beneficios que habia concedido al lactante; el cautivo sabrá reconocer mejor que el niño toda la generosidad de su benefactor. Habiendo pasado con plena conciencia de un estado de miseria y de dolor a la tranquila dicha en la que el otro ha crecido, sabe lo que representa esta bondad, y su corazón se llena de alabanzas. Mientras que, a pesar de su inteligencia, el niño no puede comprenderla porque siempre estuvo acostumbrado a tanto bienestar. Pero nadie duda de que la gracia y los favores de que se ha beneficiado son más grandes por haber sido constantes y lo obligan a mayor gratitud que la que debe el cautivo.

I16 Idem, pp. 31-32 
Asi Dios ha amado a Israel, joven niño reencontrado en Egipto, lo ha tomado entre sus brazos, lo ha cuidado...Pero Israel ignora que Dios lo salva (Oseas 11:3) ${ }^{117}$.

$\mathrm{N}^{\circ} 4$

Dos hermanos heredaron cada uno de su padre una tierra que exigia gran trabajo. La dividieron y cada uno solo tuvo su pedazo. Uno era inteligente, trabajador. El otro, exactamente lo contrario. El primero comprendió que el solo cultivo de la tierra no podría preservarlo de la necesidad de proporcionarle subsistencia. Se alquiló como obrero a fin de obtener un salario cotidiano. Al llegar la noche, habiendo terminado su jornada, cultivaba, durante una hora su huerta del mejor modo posible. Cuando tuvo suficiente dinero para no alquilarse más, dejó el trabajo de los otros para hacer el suyo con cuidado y atención. No dejó de actuar así hasta que la tierra se valorizó. Al llegar la cosecha, reunió los frutos y pudo bastarse para el año siguiente. Desde entonces pudo trabajar holgadamente su propiedad, sembrando, plantando siempre más. El fruto de sus esfuerzos fue que pudiera satisfacer sus necesidades y comprarse un segundo predio.

Cuando el hermano perezoso y tonto supo que su tierra no podía nutrirlo, la abandonó enteramente, alquilándose sin economizar jamás. Cuando tuvo suficiente dinero para dispensarse de trabajar un día, ganduleó, perdió su tiempo, se divirtió y no pensó jamás en su tierra. Cuando se daba a los otros en alquiler y le quedaba un poco de dinero libre, iba a los baños; su tierra quedaba desolada, no producía nada y se convirtió en presa de zarzales; las barreras se quebraron, la inundación arrastró los últimos árboles.

Yo he pasado cerca del campo del perezoso y cerca de la viña del necio y he aquí, que las espinas crecian en todas partes, las zarzas cubrian las superficies y el muro de piedra se habia derrumbado... (Proverbios 24:20-32) ${ }^{118}$.

$\mathrm{N}^{\circ} 5$

Se ha comparado tu suerte, oh hermano mío, a la de un niño que nació en la oscura celda de una prisión real. El rey tuvo piedad de este desheredado y ordenó darle toda la felicidad y el bienestar compatibles con su estado. Creció y llegó a la edad de la razón sin conocer nada más que su celda. Un enviado venía regularmente a visitarlo y traerle todo lo que necesitaba:

117 Idem, p. 76.

118 Idem, p. 83. 
luz, alimento, bebida, vestimenta. Le hizo conocer su estado de sujeción al rey al cual pertenecía la celda, su contenido y todas las cosas que estaban en ellas: era necesario, entonces, darle las gracias y glorificarlo.

El niño dice: "Alabo al amo de este calabozo que me tomó por súbdito, me distinguió con su beneficios, habiendo posado sus miradas sobre mi y compadecido de mi miseria".

- "Ni pronuncies estas palabras, frisan en la blasfemia. ¡El reino del amo no es este calabozo, la extensión de su reino es más vasta que esta prisión, extremadamente, indeciblemente más grande! y por lo mismo, tú no eres su único súbdito sino que una multitud de esclavos están a su servicio. Los beneficios que te acuerda, nada son junto a las gracias con que colma a otros, su providencia ante ti no es nada comparada con lo que se extiende alrededor de él".

- "No comprendo tus palabras. Conozco al rey según lo que veo de sus bondades y del gobierno de estos lugares".

- "Proclama entonces las palabras del rey Altísimo cuya realeza es eterna y cuya bondad y gracia son infinitas...Entre sus multitudes soy el menor de sus servidores. Mi vida es nada ante su grandeza omnipotente".

Y el niño aprendió lo que no comprendía de este rey muy glorioso, cuya elevación creció aún más ante sus ojos. La reverencia se enraizó en su corazón y los dones que recibió de él le parecieron más preciosos, sabiendo que era más pequeño en la inmensidad de su reino.

Y tú, hermano mio, guarda en tu corazón esta parábola, imagen de tu situación por lo que toca a la esfera que rodea la tierra. Ignoramos el contenido de nuestros menores valles, con más razón, el mundo y, más aún, la esfera celeste. Comprende y saca enseñanza, iDios es para ti como el rey para ese niño! Su gracia, Sus dones, Su amor, te parecerán más grandes sabiéndote mezclado en la multitud de sus criaturas ${ }^{119}$.

$\mathrm{N}^{\circ} 6$

El alma: Me has consolado conduciéndome a renunciar a comprender este profundo y sutil secreto. Pero devélame, te lo ruego, el misterio de mi vida, la intención que presidió mi llegada a este mundo. Así, tan brevemente como sea posible, dame una explicación aproximada del determinismo y de la justicia divina a fin de que mi suerte no sea semejante a la del rey ignorante cuya historia conozco:

119 Idem, p. 102. 
En una isla de las Indias, una ciudad tenía por costumbre darse cada año por rey a un extranjero. Terminado el año, lo enviaban nuevamente a su pais, donde él retornaba a la vida ordinaria. Entre estos elegidos, hubo una vez un tonto que ignoraba totalmente la suerte que le estaba reservada. Reunió tesoros, construyó palacios y no hizo salir nada de la ciudad. Por el contrario, puso todos sus esfuerzos en hacer venir lo que poseia fuera, bienes, mujer e hijos. Al término de un año, los habitantes de la ciudad lo expulsaron, desnudo y despojado. Le confiscaron aún lo que tenía antes, y en su exilio no tuvo nada de la ciudad ni de lo anterior. Se arrepintió y se lamentó por tantas penas y esfuerzos conducentes a amasar tesoros destinados a otros.

Luego, la ciudad eligió para soberano a un extranjero perspicaz y esclarecido. Inmediatamente después de su advenimiento, eligió un consejero, lo colmó de bienes y se informó de las costumbres del pais y del destino de los que le habian precedido en el trono. El hombre develó el secreto y las intenciones de los ciudadanos. El nuevo rey, advertido, no se ocupó en nada de lo que había absorbido a su predecesor. Se esforzó en exportar todo lo que era precioso en esa ciudad para expedirlo a otro país, donde depositó sus tesoros y sus riquezas. No se abandonó jamás a las pompas y a los honores con que lo colmaban; estuvo siempre entre la tristeza y la alegría. Se entristecia por la proximidad del exilio y de que tantas cosas deliciosas pasaran como en un sueño, pues tan rápidamente como habia sido elegido rey, seria hundido en el destierro. Pero se alegraba también, se regocijaba de abandonar pronto ese lugar para ir a donde tenía depositada todas sus riquezas; tenia el corazón alegre y el alma confiada en una perfecta plenitud de paz. Cuando terminó el año, no se entristeció por su partida sino que la apresuró, en la alegría y la serenidad que le daban las felices precauciones que había tomado. Se dirigía hacia una dicha inmensa, radiante de gloria en una alegría sin fin, feliz en sus dos condiciones y satisfecho en sus dos residencias.

La razón: Tu parábola da la imagen de tu existencia en este mundo: tú eres el segundo de los reyes sobre los que acabas de hablar. Sabes que eres un extranjero fugitivo, y así debes actuar, como ese monarca de talento del que vas a compartir el destino.

Si te desvías de su conducta, mis palabras son vanas e inútil mi discurso ${ }^{120}$.

Varios compañeros marchaban por caminos y se durmieron una noche cerca de un muro. En medio de la noche aparece un perro y ensucia a uno de ellos. Este despierta, y furioso, va a lavarse. Mientras se aleja, la pared se derrumba y mata a todos sus amigos. 
Semejantes cosas suceden a menudo, como a menudo es menester invertir los términos de nuestro relato ${ }^{121}$.

$N^{\circ} 8$

Poco después de su conversión, un asceta se dirigió a un país lejano en busca de su subsistencia. Viendo a un idólatra cerca de la ciudad hacia la cual se dirigía, le dijo: "¡A qué grado de ceguera y estupidez estáis reducidos para adorar imágenes!"

El adorador del fuego replicó: ¿Qué adoras Tú?

-Adoro al Creador, al poderoso, al alimentador, al único, el que hace subsistir, al incomparable.

- Pero tus actos contradicen tus palabras.

- ¿En qué?

- Si dices verdad, tu Dios te habrá hecho subsistir en tu país del mismo modo que te lamentas aqui y no te habrias visto obligado a ir a tierras tan lejanas.

El asceta quedó sin respuesta, y en consecuencia, retornó hacia la ciudad, de donde no salió jamás.

El abandono libera al alma y al cuerpo de las acciones dificiles, de las empresas agobiadoras salva del servicio a los reyes, de sus exigencias y de sus violencias.

El totalmente abandonado no espera las causa intermedias de la subsistencia y esto da el mayor reposo a su cuerpo, honor intacto para sí mismo, la libertad del espíritu, el espacio necesario para practicar la religión en la certidumbre de que la causa intermedia solo añade o cercena por decreto divino. Pues no es ni del oriente ni del occidente ni del desierto, que viene la subsistencia, sino de Dios que es Rey. Él abate a uno, eleva a atro $(\text { Salmos } 75 ; 23)^{122}$.

122 Idem, p. 157. 
Un asceta fue a una ciudad para enseñar a sus habitantes cómo adorar al Altísimo. Los encontró a todos cubiertos de vestiduras de un mismo color. Vio sus tumbas cavadas en el suelo de las casas y no encontró ni una sola mujer. A sus preguntas respondieron así: "Nos vestimos todos de un mismo color para que, entre nosotros, no se distinga el rico del pobre, el rico no se enorgullezca y no se gloríe de su riqueza, y que el pobre no se menosprecie, y, para ser en la tierra tal como seremos en la tumba. Hubo un rey que se mezclaba con sus servidores y no se distinguía de ellos, tan humildemente se vestía. Colocamos las tumbas de nuestros muertos en el sueño de nuestras moradas a fin de estar prevenidos por ellos y prestos a morir, cargados de nuestras provisiones de ruta para ir al lugar de reposo. Tú has visto igualmente que estamos separados de nuestras mujeres y de nuestros hijos. Sabe que le hemos reservado una ciudad cercana. Cuando uno de entre nosotros tiene necesidad de ir a visitarlos, va hacia ellos a cumplir su deber; después vuelve hacia nosotros. Pues hemos comprobado todas las preocupaciones que nos trae su presencia: ansiedad del corazón, temores y penas sin número. Su alejamiento nos da la paz. Porque hemos elegido el camino del más allá, en el menosprecio de las cosas de este mundo".

Estas palabras gustaron tanto al asceta, que los bendijo y los felicitó por su destino.

El totalmente abandonado que tiene una mujer, parientes, amigos y enemigos, debe confiar en Dios a fin de estar liberado de su responsabilidad para con ellos y esforzarse en cumplir cada uno de sus deberes, en tener buen corazón para ellos, en abstenerse de todo lo que podria causarle daño, en buscar su felicidady serles fiel en toda cosa, enseñarle los caminos de su salvación, según los deberes religiosos y mundanos, adorando al Altísimo ${ }^{123}$.

$\mathrm{N}^{\circ} 10$

Un santo tenía por vecino a un escriba muy hábil que se ganaba la vida vendiendo los libros que copiaba. Un día, le preguntó: ¿Cómo van tus negocios? El respondió: Irán bien mientras mi mano se encuentre en buen estado. La misma noche su mano se secó. No escribió más nada hasta el fin de sus dias. 
Tal fue su castigo por confiar solamente en sus dedos ${ }^{124}$.

$N^{\circ} 11$

De dos mercaderes que se dirigen a una ciudad, uno es pobre, pero con sus transacciones se multiplican sus beneficios; el otro es rico, pero inactivo y gana menos que el primero.

Es minimo el mérito de quien solamente endereza su propia alma mientras que el maestro que endereza su alma y corrige a muchos de sus hermanos, aumenta su mérito propio por el numero de aquellos que habrá suscitado en otros con relación a Dios.

Los Doctores dicen: "Ningún sobreviene a quien hace méritos a la multitud" (Avot $5: 18)^{125}$.

$N^{\circ} 12$

Se interroga a un sabio: "Por qué eres el maestro de todos tus contemporáneos?"

Respondió: "Porque no he encontrado jamás un hombre que, de alguna manera, no me parezca superior a mí. Cuando era más sabio que yo decia: él sirve a Dios mejor que lo que yo lo hago, su sabiduría lo atestigua. Cuando lo era menos que yo, yo pensaba: en el día del juicio, las cuentas que se le pedirán serán menos rigurosas; yo premedito todos mis pecados, él los comete por inadvertencia. Si era más viejo: él me ha precedido en este mundo, sus méritos son más numerosos que los míos. Si era más joven, yo reflexionaba: sin duda ha pecado menos que yo. Tenía la misma edad y la misma sabiduría: su corazón es, sin duda, más puro que el mío. Pues yo sé cuales pecados arrastro conmigo. Así los honraba a todos y me humillaba delante de ellos".

Este sabio practicaba el precepto de nuestros doctores: "Juzga a todo hombre sobre la balanza del mérito, recibe con gracia y sé extremadamente humilde de espiritu" (Avot 1:15; $4: 12)^{126}$.

124 Idem, p. 194.

I2.5 Idem, pp. 354-355.

126 Idem, p. 246. 
No sabré esperar la víspera de mi suerte porque ignoro el día de ella. Será entonces semejante a ese servidor demasiado seguro de no ser jamás apartado de la presencia del rey; él no se consagraba sino a la búsqueda de los placeres de este mundo, pensando siempre en consagrarse un día, más tarde, al servicio del amo; cuando el soberano lo hizo llamar súbitamente, para pedirle las cuentas de su oficio, no pudo proporcionarlas y fue echado no solamente de la presencia del rey sino también de todo el reino ${ }^{127}$.

$N^{\circ} 14$

Un rey ordenó a sus servidores que llevasen a un visir a la margen de un gran río, con toda clase de contemplaciones, para depositarlo en un lugar indicado a la hora indicada. Ordenó, al mismo tiempo, al visir que cumpliese ciertos actos en favor de esos mismos servidores. Estos obedecieron la orden real, el visir, por su parte, no la tuvo en cuenta. Uno de ellos tomó la palabra y dijo:

"Oh príncipe olvidadizo de las órdenes del rey, ¿no temes acaso que alguno de entre nosotros te imite y prescinda de la misión de cuidarte en tu peregrinación, dejándote caer en medio del gran río y perecer de muerte violenta? De tu error, satisface tu deuda hacia nosotros, por temor de que te abandonemos". Y el visir se arrepintió.

Y tú, oh hermano mío, piensa en lo que sucederia si alguno de tus órganos violase el conjuro divino en el momento en que quisieses hacer uso de él.

No ignores el decreto del Señor en su libro que jamás miente: "Todo en el universo esta sometido a tu voluntady a tu deseo si te sometes a Dios y todo ira contra ti si vas contra Ér" (Levítico 26:3) ${ }^{128}$.

\section{$N^{\circ} 15$}

Imagina que estás en un lugar encima del cual, detrás de ti, se cierne una forma sin que se logre percibirla y considerarla. Siguiendo un consejo, tomas una placa de acero, la pules hasta quitarle su opacidad y la untas largamente con numerosos aceites. La pones luego ante tu

127 Idem, p. 219

128 Idem, p. 281. 
mirada y descubres entonces la forma elevada que se te escapaba. Puedes contemplarla y deleitarte con su deslumbrante y magnífica belleza.

La elevada forma que nos es imposible contemplar con la mirada es la ciencia suprema; el poder del Altísimo es el esplendor del mundo espiritual que escapa a nuestros sentidos. La placa de acero es el alma humana; el pulimento es el ejercicio en la sabiduría y en las disciplinas racionales y reveladas. Finalmente, la untura es el examen de conciencia cuyos treinta métodos hemos determinado ${ }^{129}$. 